\title{
Tax-1 and Tax-2 similarities and differences: focus on post-translational modifications and NF-кB activation
}

\author{
Margret Shirinian, Youmna Kfoury, Zeina Dassouki, Hiba El-Hajj and Ali Bazarbachi*
}

Department of Internal Medicine, Faculty of Medicine, American University of Beirut, Beirut, Lebanon

\section{Edited by:}

Umberto Bertazzoni, University of

Verona, Italy

Reviewed by:

Youichi Suzuki, National University of Singapore, Singapore

Masao Matsuoka, Institute for Virus Research Kyoto University, Japan

*Correspondence:

Ali Bazarbachi, Department of Internal Medicine, Faculty of

Medicine, American University

of Beirut, P.O. Box 113-6044, Beirut,

Lebanon

e-mail: bazarbac@aub.edu.lb

\begin{abstract}
Although human T cell leukemia virus type 1 and 2 (HTLV-1 and HTLV-2) share similar genetic organization, they have major differences in their pathogenesis and disease manifestation. HTLV-1 is capable of transforming T lymphocytes in infected patients resulting in adult T cell leukemia/lymphoma whereas HTLV-2 is not clearly associated with lymphoproliferative diseases. Numerous studies have provided accumulating evidence on the involvement of the viral transactivators Tax-1 versus Tax- 2 in T cell transformation. Tax- 1 is a potent transcriptional activator of both viral and cellular genes. Tax-1 post-translational modifications and specifically ubiquitylation and SUMOylation have been implicated in nuclear factorkappaB (NF-kB) activation and may contribute to its transformation capacity. Although Tax-2 has similar protein structure compared to Tax-1, the two proteins display differences both in their protein-protein interaction and activation of signal transduction pathways. Recent studies on Tax-2 have suggested ubiquitylation and SUMOylation independent mechanisms of NF- $\mathrm{KB}$ activation. In this present review, structural and functional differences between Tax1 and Tax-2 will be summarized. Specifically, we will address their subcellular localization, nuclear trafficking and their effect on cellular regulatory proteins. A special attention will be given to Tax-1/Tax-2 post-translational modification such as ubiquitylation, SUMOylation, phosphorylation, acetylation, NF- $\mathrm{kB}$ activation, and protein-protein interactions involved in oncogenecity both in vivo and in vitro.
\end{abstract}

Keywords: HTLV-1, HTLV-2, Tax-1, Tax-2, NF-kB

\section{INTRODUCTION}

Human T cell lymphotropic virus type 1 (HTLV-1) and type 2 (HTLV-2) are closely related human delta retroviruses. Although currently there are four known types of HTLV retroviruses (Mahieux and Gessain, 2005, 2009), HTLV-1 is the most pathogenic of all and the first oncogenic retrovirus discovered in humans. HTLV-1 infects 15-20 million individuals worldwide. It is transmitted horizontally (sexual transmission), vertically (mother to child), and by blood transfusion (Kaplan et al., 1996). HTLV-1 is the causative agent of adult T cell leukemia/lymphoma (ATL; Poiesz et al., 1980a,b; Gallo, 1981; Hinuma, 1982; Hinuma et al., 1982; Yoshida et al., 1982) and tropical spastic paraparesis/HTLV1-associated myelopathy (TSP/HAM), a distinct neurological disorder with inflammatory symptoms and incomplete paralysis of the limbs (Gessain et al., 1986). HTLV-1 infection is endemic in Japan, Africa, South America, the Caribbean, Melanesia, and certain areas in the Middle East and Eastern Europe (reviewed in Gessain and Mahieux, 2000; Tarhini et al., 2009). The HTLV-1 transactivator protein, Tax-1, has been identified as a significantly potent protein in HTLV-1 pathogenesis. It works as an activator of a variety of transcription factors and has been shown to be sufficient to immortalize $\mathrm{T}$ cells in vitro and in vivo thus playing an important role in cellular transformation (Cereseto et al., 1996; Yao and Wigdahl, 2000; Grassmann et al., 2005; Kashanchi and Brady, 2005; Kfoury et al., 2005; Hasegawa et al., 2006; Mahieux and Gessain, 2007; Matsuoka and Jeang, 2007; Yoshida et al., 2008; Matsuoka and Green, 2009; Yamazaki et al., 2009). HTLV-2, however, was first identified in a $\mathrm{T}$ cell line established from a patient with hairy-cell leukemia (Kalyanaraman et al., 1982). In contrast to HTLV-1, HTLV-2 infection has not been linked to the development of lymphoproliferative disorders. However, as in HTLV-1, HTLV-2 infection has been associated with sporadic cases of myelopathy resembling TSP/HAM caused by HTLV1 (Roucoux and Murphy, 2004). HTLV-2 infection is mainly concentrated in Central and West Africa (Goubau et al., 1990; Gessain etal., 1993), native Amerindian populations in North, Central, and South America (Hjelle et al., 1990; Lairmore et al., 1990; Heneine et al., 1991; Levine et al., 1993), and among intravenous drug users in the United States and Europe (Gazzard et al., 1984; Gallo etal., 1986; Khabbaz etal., 1991; Toro et al., 2005).

\section{Tax-1 AND Tax-2: THEY LOOK SIMILAR BUT ARE QUITE DIFFERENT SEQUENCE AND STRUCTURAL ORGANIZATION}

Both Tax-1 and Tax-2 are required for HTLV-1 and HTLV-2 viral replication and they play an important role in proviral transcription (Landry et al., 2007; Yoshida et al., 2008). In addition, Tax-1 is a key player in immortalization and transformation of infected $\mathrm{T}$ cells by enhancing the transcriptional expression of genes that control $\mathrm{T}$ cell proliferation, affecting genes involved in mitotic checkpoints and further inactivating tumor suppressor pathways (Peloponese et al., 2007; Boxus et al., 2008; Journo et al., 2009; Chlichlia and Khazaie, 2010). 
Tax-1 and Tax-2 share overall sequence homology (Figure 1A), but have distinctive differences both at the structural and functional levels (Higuchi and Fujii, 2009; Bertazzoni et al., 2011). Tax-1 is a $353 \mathrm{aa}$ (amino acid) residue protein, which is highly conserved in all HTLV-1 serotypes. Of the four serotypes of HTLV-2, Tax-2 subtype A and B are the best characterized (Sheehy et al., 2006) and Tax-2B is the subtype which is represented in Figure 1. Tax-2B has 356 amino acid residues, whereas Tax-2A possesses a 25 amino acid truncation at the $\mathrm{C}$-terminus. Tax- 1 and Tax- $2 \mathrm{~B}$ share $85 \%$ amino acid sequence similarity and have several common domains (Figure 1A).

The N-terminal region of both Tax-1 and Tax- 2 contain CREB (cyclic AMP responsive element binding)-activating domain and a zinc finger domain (Ross et al., 1997; Feuer and Green, 2005; Figure 1B). The CREB domain is required for activation of the viral promoter (Giebler et al., 1997; Boxus et al., 2008). Depending on the cell type, Tax-1 mutants deficient for CREB activation are incompetent for transformation or induction of aneuploidy (Akagi et al., 1997; de la Fuente et al., 2006; Geiger et al., 2008). The zinc finger domain is required for association with a variety of transcription factors including the p62 nucleoporin and mutations in this motif abolishes Tax- 1 interaction with p62 and nuclear import (Tsuji et al., 2007). Within the first 60 amino acids of Tax-1, there is a nuclear localization signal NLS (Gitlin et al., 1991; Smith and Greene, 1992) whereas the first 42 amino acid sequence of Tax2 contain a nuclear localization determinant (Turci et al., 2006)

A

Tax1 MAHFPGFGQSLLFGYPVYVFGDCVQDDWCPISGGLCSARLHRHALIATCPEHQITWDPID 60 Tax2 MAHFPGFGQSLLYGYFVYVGDCVQADWCPVSGGLCSTRLHRHALIATCPEHQLTWDPID 60

Tax1 GRVIGSÄLQFLIPRLPSFPTQRTSKTLKVLTPPITHTT PNIPPSFLQAMRKYSPFRNGYM 120 Tax2 GHVVSPLQYLIPRLPSFPTQRTSKTLKVLTPPTTPVSPKVPPAFFQSMRKHTPYRNGCL 120

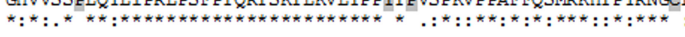

Tax1 EPTLGQHLPTLSFPDPGLRPQNLYTLWGGSVWCMYYQLSPPITWPLLPHVIFCHPGQLG 180 Tax2 EPTIGDQLPSLAFPE PGLRPQNVYTTWGKTWCLYLFQISPPMTWPLI PHVIFCHPRQLG 180

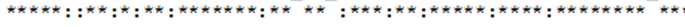

Tax1 AFLTNVPYKRIEELLYKISLTTGALIILPEDCLPTTLFQPARAPVTLTAWQNGLLPFHST 240 Tax2 AFLTKVPLKRLEELLYKMFLHTGAVIVLPEDDLPTTMFQPVRAPCIQTANCTGLIPYHSI 240

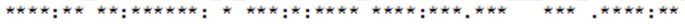

Tax1 LTTPGLIWTFTDGT PMISGPCPKDGQPSLVLQSSSFIFHKFQTKAYHPSFLISHGLIQYS 300 Tax2 LTTPGLIWT FNDGSPMISGPCPKAGQPSLVVSSLLIFEKFQTKAFHPSYLISHQLIQYS 300

Tax1 SFHSLHLLFEEYTNIPISLLFNEKEADDNDHE PQISPGGLEPPSEKHFRETEV---- 353

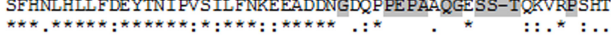

B

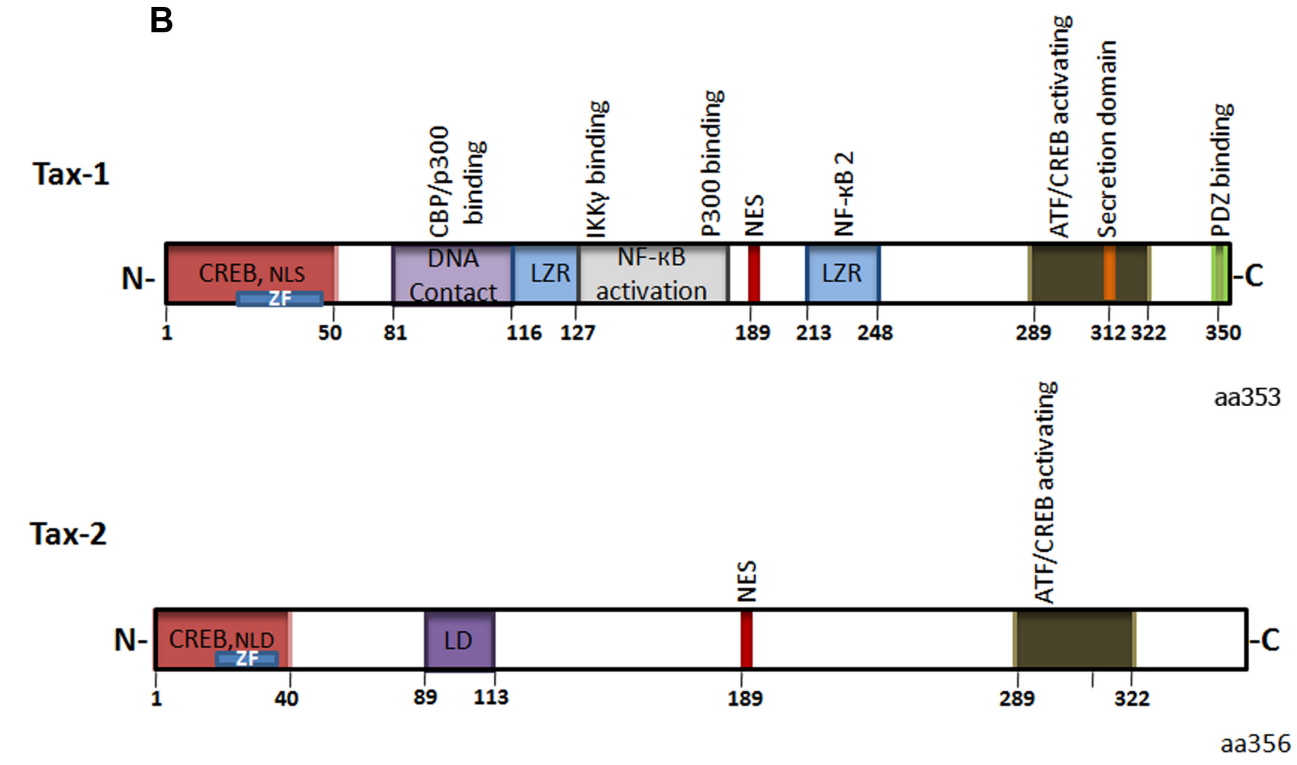

$\begin{array}{ll}\text { NLS= Nuclear localization signal } & \text { NLD= Nuclear localization domain } \\ \text { NES= Nuclear export signal } & \text { LZR= Leucine zipper region } \\ \text { ZF= Zinc Finger motif } & \text { LD }=\text { Localization domain }\end{array}$

FIGURE 1 | (A) Amino acid sequence alignment of Tax-1 and Tax-2 $\left({ }^{*}\right)$ represent identical amino acids, (:) conserved amino acid substitutions, (.) semi-conserved substitutions, differences are shaded. (B) Schematic representation of Tax-1 and Tax-2 structural and functional domains. 
required for its nuclear functionality (Figure 1B). Furthermore, Tax-2 has an additional cytoplasmic localization domain about 10 amino acids long, situated at amino acid position 89-113 which has been shown to be responsible for its divergent localization compared to Tax-1 (Meertens et al., 2004).

The central region of Tax-1 includes two leucine zipperlike regions (LZR), which are known to be essential for protein dimerization and DNA interaction (Jin and Jeang, 1997; Basbous et al., 2003; Boxus et al., 2008). The first LZR is located at amino acid position 116-145 and is responsible for non-canonical nuclear factor-kappaB (NF- $\mathrm{B}$ ) activation and protein dimerization whereas the second LZR is located at amino acid position 225-232 and is responsible for p100 processing and p52 nuclear translocation involved in NF-кB2 activation (Xiao et al., 2001; Higuchi et al., 2007; Shoji et al., 2009; Figure 1B). Importantly, Tax-2 lacks these two LZR regions. Both Tax-1 and Tax-2 have nuclear export signal (NES) located at amino acid position 189202 (Alefantis etal., 2003; Chevalier et al., 2005; Figure 1B). Furthermore, Tax-1 and Tax-2 have at the C-terminal region CREB/activating transcription factor (ATF)-activating domain, essential for transactivation of the CREB/ATF and for NF- $\kappa$ B/Rel signaling pathways (Ross et al., 1997; Figure 1B).

Tax-1 interacts in vitro with a number of proteins of the CREB/ATF family of transcription factors: CREB, CREM (cyclic AMP responsive element modulator), ATF1, ATF2, ATF3, ATF4 (also named CREB2), and XBP1 (X-box-binding protein 1; Zhao and Giam, 1992; Franklin etal., 1993; Bantignies et al., 1996; Reddy et al., 1997). These proteins share a common cluster of basic residues allowing DNA binding, and a leucine zipper (bZip) domain involved in homo and hetero-dimerization. Dimer formation modulates their DNA-binding specificity and transcriptional activity (Hai and Hartman, 2001). Tax-1, but not Tax-2, possesses at its C-terminus a PDZ-binding motif (Figure 1B). Indeed, PDZ domain-containing proteins play a key role in recruiting and organizing the appropriate proteins to sites of cellular signaling, as well as polar sites of cell-cell communication (Fanning and Anderson, 1999; Harris and Lim, 2001; Sheng and Sala, 2001). The PDZ domain of Tax-1 has been shown to interact with the human homolog of the Drosophila melanogaster disc large tumor suppressor protein hDLG (homolog of Drosophila disc large), which regulates cellular proliferation and cell cycle phase transition (Rousset et al., 1998; Higuchi and Fujii, 2009). Tax-1 competes with the binding domain of hDLG and APC (The adenomatous polyposis coli) tumor suppressor protein and rescues cells from cell cycle arrest induced by hDLG (Suzuki et al., 1999; Hirata et al., 2004).

Tax- 1 but not Tax- 2 contain additionally at the C-terminus a secretory signal which is involved in Tax-1 secretion and transport from endoplasmic reticulum to Golgi and in movement from Golgi to the plasma membrane (Alefantis et al., 2003, 2005). The secretory sequence at the C-terminus requires interaction with secretory carrier membrane proteins (SCAMP-1 and SNAP 23) and the coat protein 2 (COPII; Jain et al., 2007). Recently, the C-terminus of Tax-1 has received much attention due to the presence of domains that are unique for Tax-1 and may partially explain the highest transformation capacity of Tax-1 in comparison to Tax-2. Indeed, the C-terminal 53 amino acids of Tax-1 is responsible for increased transformation efficiency in rodent fibroblasts (Majone et al., 1993).

\section{CELLULAR LOCALIZATION OF Tax-1 AND Tax-2}

Early studies on Tax-1 and Tax-2 subcellular localization have demonstrated that Tax-1 localizes in the nucleus and Tax-2 in the cytoplasm of HTLV-infected cells (Semmes and Jeang, 1996; Meertens et al., 2004). Both Tax-1 and Tax-2 contain a nuclear localization signal at the N-terminus, however, Tax-2 contains an additional cytoplasmic localization domain at position 89-113. By using series of Tax-1/Tax-2 chimeras, Meertens et al. (2004) have shown that this stretch of sequence indeed contributes to the difference in Tax-2 cytoplasmic localization compared to Tax-1.

In various Tax-1/Tax- 2 transfected cells lines, Tax-1 has a punctate nuclear distribution and localizes in nuclear structures named nuclear speckles or bodies (Semmes and Jeang, 1996; Bex et al., 1997), whereas Tax-2 was predominantly present in the cytoplasm (Meertens et al., 2004). In these nuclear bodies, Tax-1 colocalizes with proteins of the splicing machinery such as splicing factors $\mathrm{Sm}$ and SC-35, transcriptional components including the largest subunit of RNA polymerase II and cyclin-dependent kinase CDK8 and with important components of NF- $\mathrm{B}$ such as the two subunits p50 and RelA, as well as the regulatory subunit NEMO of IkappaB kinase (IKK; Bex et al., 1997). Furthermore, recent findings indicate that Tax-1 colocalizes within nuclear bodies with small ubiquitin modifiers (SUMO-1, 2, and 3; Lamsoul et al., 2005; Nasr et al., 2006) and with the SUMO E2 ligase Ubc-9 (Kfoury et al., 2011).

Although Tax-1 has been shown to be chiefly abundant in the nucleus, many studies reported cytoplasmic expression of Tax-1 in both Tax-1 transfected and HTLV-1-infected cell lines (Burton et al., 2000; Cheng et al., 2001). In the cytoplasm, Tax1 targets Iк $\mathrm{B} \alpha$ and I $\mathrm{B} \beta$ for phosphorylation, ubiquitylation, and proteasome-mediated degradation, promoting the nuclear translocation of NF- $\mathrm{B} / \mathrm{Rel}$ proteins and the transcription induction of many cellular genes (Nicot etal., 1998). Within the cytoplasm, Tax-1 localizes in organelles associated with secretory pathways, structures associated to the centrosome or microtubule organizing center (MTOC), and in the cell to cell contact regions termed virological synapses (Igakura et al., 2003; Alefantis et al., 2005; Kfoury et al., 2008; Nejmeddine et al., 2009). In contrast, Tax-2 has been shown initially to be mostly cytoplasmic with no clear evidence for localization in nuclear bodies (Meertens et al., 2004). However, a recent study reported Tax- 2 punctate distribution in nuclear bodies and colocalization with the Rel A subunit of NF-кB (Turci et al., 2006, 2009).

Interestingly, the post-translational modifications of Tax-1 control its sub cellular localization and its ability to activate the NF- $\kappa$ B pathway. More specifically, Tax-1 is subjected to multiple post-translational modifications such as phosphorylation (Bex et al., 1999), ubiquitylation, SUMOylation (Chiari et al., 2004; Lamsoul et al., 2005; Nasr et al., 2006), and acetylation (Lodewick et al., 2009). Ubiquitylated Tax-1 binds and recruits the IKK subunits at a centrosome-associated signalosome leading to the release of active IKK (Nasr et al., 2006; Kfoury et al., 2008). Using livecell imaging, Kfoury et al. (2011) also showed that Tax-1 shuttles between nuclear bodies and the centrosome, depending on its ubiquitylation and SUMOylation status. 
Finally, Tax-1 interacts with histone methyltransferase (HMTase) SMYD3 which affects its nucleo-cytoplasmic shuttling and regulates NF-кB activation (Yamamoto et al., 2011). Interaction of Tax-1 with the four and a half LIM domain protein 3 (FHL3) also affects Tax-1 sub cellular localization and transactivation capacity (Mccabe et al., 2013).

\section{MODULATION OF CELLULAR PATHWAYS BY Tax-1 AND Tax-2}

Tax-1 interacts with various components of the cell signaling system which control cell transformation, proliferation, intracellular protein distribution, cell migration, and virological synapses (Azran et al., 2004; Jeang et al., 2004; Grassmann et al., 2005; Boxus et al., 2008). More than 100 proteins have been reported to interact with Tax-1 (Boxus et al., 2008). Tax-2, however, interacts with a limited number of partners and most of them belong to the $\mathrm{NF}-\kappa \mathrm{B}$ family of proteins. It is important to note that Tax-1 and to a lesser extent Tax-2 interactome is undergoing a dramatic expansion with additional interaction partners being discovered continuously.

\section{PI3K AND AKT PATHWAY}

Phospho-inositol triphosphate kinase (PI3K) and its downstream kinase AKT/PKB (protein kinase B) are activated in T cells by many cytokines including interleukin 2 (IL-2), and provide cell survival and growth signals (Cantley, 2002). PI3K activation results in phosphorylation of $\mathrm{AKT}$ at $\mathrm{Ser}^{473}$ which in turn activates a broad range of regulatory proteins and transcription factors such as AP1 (Zhang et al., 2007). In both HTLV-1 transformed and ATL cells, the transcription factor AP1 and hence the PI3K/AKT pathway are constitutively active (Fukuda et al., 2005; Peloponese and Jeang, 2006). The PI3K inhibitor (LY294002) or the AKT inhibitor II were shown to induce cell cycle arrest at G1 phase in HTLV-1 transformed cells through p27/Kip1 accumulation, and thus subsequently induce caspase-9-dependent apoptosis (Jeong et al., 2008). Other studies have shown an important role for PI3K/AKT pathway in regulating telomerase activity, and inhibition of PI3K decreased telomerase activity by more than $50 \%$ in HTLV-1-infected cells (Bellon and Nicot, 2008). Tax-1 has been also shown to be involved in Forkhead Box O (FoxO) down regulation, an AKT downstream effector and a tumor suppressor, through the ubiquitin-proteasome pathway (Oteiza and Mechti, 2011). Conversely, a recent study demonstrated that Tax-2 efficiently immortalized human primary $\mathrm{CD} 4^{+}$memory $\mathrm{T}$ cells by constitutively activating various signaling pathways including the PI3K/AKT pathway and further found that Tax-2 induced autophagy by interacting with the autophagy complex that contains Beclin 1 and PI3K class III to form autophagosomes (Ren et al., 2012).

\section{MAPK SIGNALING PATHWAY}

Mitogen-activated protein kinases (MAPKs) are serine/threoninespecific protein kinases that respond to external mitogen stimuli such as growth factors, cytokines or physical stress. MAPK signaling involves a sequential phosphorylation cascade of MAP kinase kinase kinase (MAP3K). There are at least five distinct MAPK subgroups: the extracellular signal-regulated kinases protein homologs 1 and 2 (ERK1/2), the big MAPK-1 (BMK-1) also referred to as ERK5, the stress-activated protein kinases-1 (SAPK1) better known as the c-Jun N-terminal kinase homologs 1,2 , and $3(\mathrm{JNK} 1 / 2 / 3)$, the (SAPK-2) homologs $(\mathrm{p} 38 \alpha / \beta / \mathrm{d})$ and finally ERK6 also known as p38 $\gamma$ (Pimienta and Pascual, 2007). Tax1 binds the MAP3K MEKK1 to stimulate IKK- $\beta$ kinase activity and NF- $\kappa$ B activation (Yin et al., 1998). TGF- $\beta$-activating kinase 1 (TAK1) is the other MAP3K which interacts with Tax-1 and phosphorylates IKK- $\beta$ and MKK6 (MAP2K6) serine/threonine kinase, thereby activating NF- $\mathrm{B}$ and JNK (Adhikari et al., 2007). Tax-2 interaction with the MAPK signaling pathway leading to its constitutive activation have also been recently reported (Ren et al., 2012).

\section{TGF $\beta$ SIGNALING PATHWAY}

Transforming growth factor $\beta$ (TGF $\beta$ ) inhibits $\mathrm{T}$ cell growth in mid-G1 but can also promote tumorigenesis (Pennison and Pasche, 2007). TGF $\beta$ binds to a heterodimeric complex composed of type I (T $\beta R I)$ and type II (T $\beta$ RII) serine/threonine kinase receptors and activates downstream targets such as Smad proteins. These include receptor-activated R-Smad (Smad1-23-5-8) and the common mediator Co-Smad (Smad4). Smad4 containing complexes then translocate to the nucleus and activate transcription of genes under the control of a Smad-binding element (Waterston and Davies, 1993).

Adult T cell leukemia/lymphoma cells produce high levels of TGF $\beta$ in the sera of HTLV-1-infected patients due to constitutive activation of AP-1 in the PI3K/AKT pathway (Kim et al., 1990). Tax-1 binds the N-terminus of Smad2, Smad3, and Smad4 proteins, which inhibits their association with Smad-binding elements and competes with Smads for recruitment of CBP/P300. This inhibition will also result in promoting resistance of HTLV-1-infected cells to TGF $\beta$ (Mori et al., 2001; Arnulf et al., 2002; Lee et al., 2002). So far, interaction of Tax-2 with Smads has not been reported.

\section{G PROTEINS AND CYTOSKELETAL ORGANIZATION}

The guanine nucleotide-binding proteins GTPases (G proteins) are molecular switches that cycle between active (GTP-bound) and inactive (GDP-bound) states. Tax-1 forms complexes with several members of the small GTPase Rho family G proteins such as RhoA, Rac, Gap1m, and Cdc42 (Wu et al., 2004). Rho GTPases are activated in response to external stimuli such as growth factors, stress, or cytokines. Following activation, they regulate a variety of cellular and biochemical functions such as cytoskeleton organization, regulation of gene expression, and enzymatic activities (Jaffe and Hall, 2005).

Tax-1 binds to proteins involved in cytoskeleton structure and dynamics such as $\alpha$-internexin, cytokeratin, actin, gelsolin, annexin, and $\gamma$-tubulin (Trihn et al., 1997; Reddy et al., 1998; Wu et al., 2004; Kfoury et al., 2008) and through these interactions it might connect Rho GTPases to their targets and affects cytoskeletal organization. Tax- 1 binds the $\mathrm{G} \beta$ subunit of the $\mathrm{G}$ protein-coupled receptor (GPCR) affecting the SDF-1-dependent activation of CXCR4 GPCR chemokine receptor resulting in MAPK pathway over-activation and increased cell chemotaxis (Ohshima, 2007). Additionally, Tax-1 expression at the microtubule assembly center and the Golgi in the cell to cell contact region has been shown to contribute to the intracellular signal which synergizes with 
ICAM-1 (intracellular adhesion molecule) to induce T cell microtubule polarization at the virological synapse (Nejmeddine et al., 2005, 2009). Tax-2, however, has not yet been reported to associate with proteins involved in cytoskeletal rearrangement. It is of importance to mention again that Tax-2 lacks a PDZ domain (Figure 1). This PDZ domain might contribute to Tax-1 binding to proteins involved in microtubule and cytoskeleton organization, which in turn may play an important role in pathogenicity and transformation capacity (Endo et al., 2002; Ishioka et al., 2006).

\section{ACTIVATION OF CREB SIGNALING}

As mentioned previously, both Tax-1 and Tax-2, respectively, act as transcriptional activators of the HTLV long terminal repeat (LTR). Tax-1 and Tax-2 modulate CREB and ATF function (Jeang et al., 1988; Adya and Giam, 1995; Bodor et al., 1995; Brauweiler et al., 1995; Yin et al., 1995b; Bantignies et al., 1996; Tie et al., 1996; Yin and Gaynor, 1996; Bex et al., 1998). Tax-1/Tax-2 activation of the CREB/ATF pathway is critical for efficient viral gene expression and replication (Zhao and Giam, 1992; Wagner and Green, 1993; Adya et al., 1994; Anderson and Dynan, 1994; Yin et al., 1995a; Bantignies et al., 1996). A number of mutants in both Tax1 and Tax-2 have been described that selectively abrogate the ability of Tax to activate transcription through the CREB/ATF signaling pathway (Smith and Greene, 1990; Semmes and Jeang, 1992; Ross et al., 1997). Tax-1 activates a variety of cellular genes through its interactions with CREB/ATF proteins, for example those encoding IL-17 or c-fos (Alexandre and Verrier, 1991; Dodon et al., 2004). On the other hand, Tax-1 also represses expression of genes like cyclin A, p53, and c-myb by targeting CREB/ATF factors (Nicot et al., 2000; Kibler and Jeang, 2001). Furthermore, Tax-1 has been shown to repress Smad-dependent TGF $\beta$ signaling through interaction with CBP/p300 (Mori et al., 2001). Tax-1 has also been shown to abrogate p53-induced cell cycle arrest and apoptosis through its CREB/ATF functional domain (Mulloy et al., 1998). Some bioinformatic analysis of wild type and CREB-deficient Tax-1 protein revealed several cellular genes controlled by CRE elements activated by Tax-1 (de la Fuente et al., 2006) such as Sgt1 (suppressor of G2 allele of SKP1) and p97 (Vcp; valosin containing protein) which have functions in spindle formation and disassembly, respectively.

Both Tax-1 and Tax-2 interact with a series of CREB/ATF factors and modulate expression of viral and cellular genes through CRE elements. However, the specific binding of each CREB/ATF member still needs to be studied, although some in vitro analysis suggest Tax-1 interaction with a number of proteins of the CREB/ATF family of transcription factors: CREB, CREM, ATF1, ATF2, ATF3, ATF4 (also named CREB2), and XBP1 (Zhao and Giam, 1992; Franklin et al., 1993; Bantignies et al., 1996; Reddy et al., 1997).

\section{REPRESSION OF P53 SIGNALING}

P53 is a DNA-binding transcription factor, which plays an important role as a tumor suppressor and is primarily involved in cell cycle regulation, apoptosis, and DNA repair (Vousden and Lu, 2002; Zenz et al., 2008). The P53 gene is very often mutated in human tumors and hematologic malignancies (Xu-Monette et al., 2012). Several in vitro studies in different cell types have shown that Tax-1 represses p53 activity through different mechanisms including NF- $\mathrm{B}$ activation and/or the CREB pathway (Ariumi et al., 2000; Pise-Masison et al., 2000; Jeong et al., 2004, 2005). Recently, Wip-1 phosphatase protein was shown to interact with Tax-1 and inhibits p53 (Zane et al., 2012). In this study authors have used Tax transgenic mice and found significant differences in Tax-1-driven inactivation of p53 versus p53 inactivation due to genetic mutations. Several studies explored Tax- 2 contribution to p53 inactivation. In HTLV-2 subtype A- and B-infected cells, both Tax-2B and to a lesser extent Tax-2A were shown to inhibit p53 in T cells (Mahieux et al., 2000b).

In ATL-derived cell lines, P53 has been shown to be very often inactive and sometimes mutated despite its high expression levels and this activation has been shown to be dependent on Tax-1induced NF- $\kappa$ B activation through phosphorylation of p53 Ser-15 and Ser-392 (Pise-Masison et al., 2000). Studies by Ariumi et al. (2000) have shown that the phosphorylation of p53 on Ser-15 is not a major cause of the Tax-mediated inactivation of p53. However, Tax with a mutation in the coactivator CBP-binding site (K88A), which activates NF- $\kappa B$ but not the CREB pathway, could not repress the $\mathrm{p} 53$ transactivation function. A study dedicated to Tax- 2 inhibition of p53 was performed by (Mahieux et al., 2000a) where abundant levels of p53 protein were detected in both HTLV-2A and -2B virus-infected cell lines and p53 was shown to be inactive. Furthermore, they showed that although Tax-2A and Tax-2B inactivate $\mathrm{p} 53$, the Tax-2A protein appeared to inhibit $\mathrm{p} 53$ function less efficiently than either Tax-1 or Tax-2B. Jurkat cells that constitutively express Tax-1 and Tax-2 showed reduced cellular replication, and Tax-1 inhibition of cellular replication was higher in comparison to Tax-2 (Sieburg et al., 2004).

\section{ACTIVATION OF THE NF-KB PATHWAY Generalities on $\mathbf{N F}-\boldsymbol{\kappa} \boldsymbol{B}$}

Nuclear factor-kappaB is a family of transcription factors that play a crucial role in proliferation, apoptosis, oncogenesis, and immune response. To date, five members of NF- $\kappa$ B have been described: p65 (RelA), c-Rel, RelB, p50/p105, and p52/p100. The precursor proteins p105 and p100 are processed proteolytically to the mature p50 and p52 forms, respectively (Ghosh and Hayden, 2008). All five members share a common Rel homology domain, which is a conserved domain of 300 amino acids that contains a DNAbinding domain, a dimerization domain, a region of interaction with inhibitory proteins I $\mathrm{B}$, and a NLS (Baeuerle and Henkel, 1994; Baldwin, 1996). These proteins are capable of homo- or heterodimerization using all possible combinations, except for RelB which dimerizes only with p50 or p52 (Ryseck et al., 1992).

In resting cells, NF- $\kappa \mathrm{B}$ dimers are trapped in the cytoplasm by

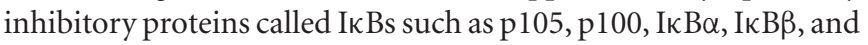
I $\kappa \mathrm{B} \gamma$ which mask the nuclear localization signal of NF- $\kappa \mathrm{B}$ factors through physical interaction (Siebenlist et al., 1994; Perkins, 2007). NF- $\kappa \mathrm{B}$ activation involves phosphorylation of I $\mathrm{B}$ inhibitors by the IKK, which triggers their ubiquitylation and subsequent proteasomal degradation, resulting in nuclear translocation of NF- $\kappa$ B dimers (Karin and Ben-Neriah, 2000; Perkins, 2007).

Nuclear factor-kappaB is activated by a wide variety of signals through two distinct pathways: the canonical and the non-canonical pathways. The canonical pathway is activated by 
pathogens, cytokines, and antigen receptors and involves the degradation of one of the three canonical I $\mathrm{B}$ molecules: I $\mathrm{B}-\alpha$, I $\kappa$ B $-\beta$, and Iк $\mathrm{B}-\varepsilon$ and the nuclear translocation of the heterodimers that essentially contain RelA (Silverman and Maniatis, 2001). In response to activating signal, the I $\mathrm{B}$ proteins are phosphorylated by the IKK complex, which is a high molecular weight complex composed of one regulatory subunit IKK- $\gamma$ (NEMO) in addition to two catalytic subunits IKK- $\alpha$ and IKK- $\beta$ (Israel, 2010). Upon activation, the IKK complex is able to induce the phosphorylation of the I $\kappa$ B proteins leading to their ubiquitylation and degradation by the proteosome. The non-canonical NF- $\kappa$ B pathway on the other hand primarily involves IKK- $\alpha$ activation upon phosphorylation by NF- $\kappa$ B-inducing kinase (NIK). IKK- $\alpha$ then phosphorylates the C-terminal region of p100 leading to subsequent processing of the p100/RelB complex into p52/RelB and its translocation into the nucleus (Dejardin, 2006). It is important to note that p52/RelB and p50/RelA dimers target distinct NF- $\kappa$ B enhancers thereby activating different subset of genes.

\section{Tax-1 activation of the NF- $\kappa$ B pathway}

Tax- 1 activates both the canonical and the non-canonical pathways resulting in constitutive activation of NF- $\mathrm{B}$ in HTLV-1-infected cells (Xiao et al., 2001; Higuchi et al., 2007). In the canonical pathway, Tax- 1 associates with the IKK- $\gamma /$ NEMO subunit (Harhaj and Sun, 1999; Jin et al., 1999; Kfoury et al., 2005) and activates upstream kinases such as MAPK/ERK kinase kinase 1 (MEKK1), and TAK1 through TAK1-binding protein 2 (TAB2; Yin et al., 1998; Wu and Sun, 2007; Figure 2A). Tax-1 therefore, connects activated kinases to the IKK complex and forces the phosphorylation of IKK$\alpha$ and IKK- $\beta$ leading to IKK activation, which results in phosphorylation, ubiquitylation, and proteasome-mediated degradation of

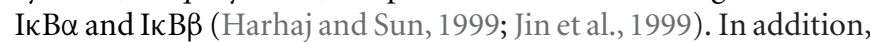
Tax- 1 binds directly to the IKK- $\alpha$ and IKK- $\beta$ subunits and activates their kinase activity independently of the upstream kinases (Chu et al., 1998; Figure 2A). In fact, silencing of MEKK1 and TAK1 does not impair Tax-1-induced NF- $\kappa \mathrm{B}$ activation (Gohda et al., 2007). Within the canonical pathway, Tax-1 can as well bind directly to I $\mathrm{B}$ Bs and mediate their degradation independently of IKK phosphorylation (Hirai et al., 1994; Suzuki et al., 1995). At the proteosomal level, Tax-1 interacts with the two subunits of the 20S proteasome (HsN3 and HC9), favors anchorage of p105 and accelerates its proteolysis (Rousset et al., 1996; Figure 2A). Tax1 therefore, leads to IкB degradation at multiple levels, thereby allowing nuclear translocation of NF- $\kappa \mathrm{B}$ independently of external stimuli. In the non-canonical pathway, Tax-1 interacts with IKK- $\gamma$ (NEMO) and p100, induces p100 processing and nuclear translocation of the p52/RelB dimer (Figure 2A). It therefore appears that IKK- $\gamma$ is an important Tax-1-binding partner for activation of both pathways (Xiao et al., 2001; Higuchi et al., 2007).

\section{Tax-2 activation of the NF- $\kappa$ B pathway}

Many studies have shown the ability of Tax-2 to activate the canonical NF- $\kappa$ B pathway to a level comparable to Tax-1 (Higuchi et al., 2007). The major difference between Tax-1 and Tax-2 lies in the inability of Tax-2 to process p100 (Higuchi et al., 2007; Figure 2B). The LZR at amino acid 225-232 of Tax-1, which is missing in Tax2 , is responsible for $\mathrm{p} 100$ processing and p52 nuclear translocation

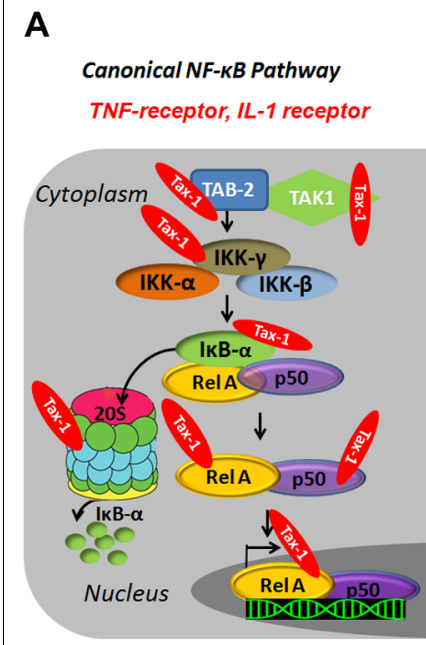

Activation by Tax-1

B

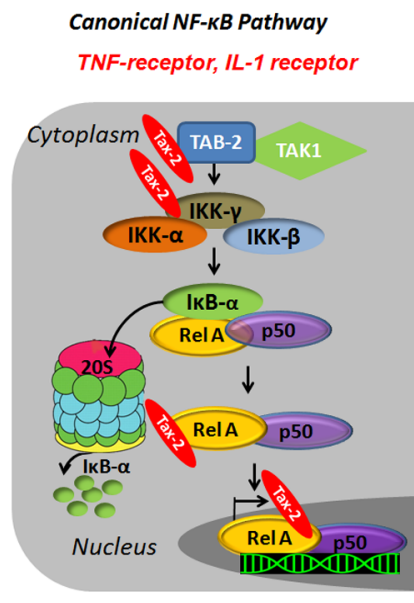

Activation by Tax-2
Non-canonical NF-кB Pathway CD40, lymphotoxin $\beta$ receptor, BAFF receptor

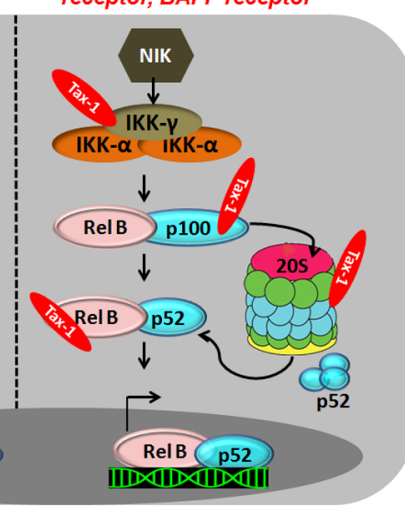

Activation by Tax-1

Non-canonical NF-кB Pathway

CD40, lymphotoxin $\beta$ receptor, BAFF receptor

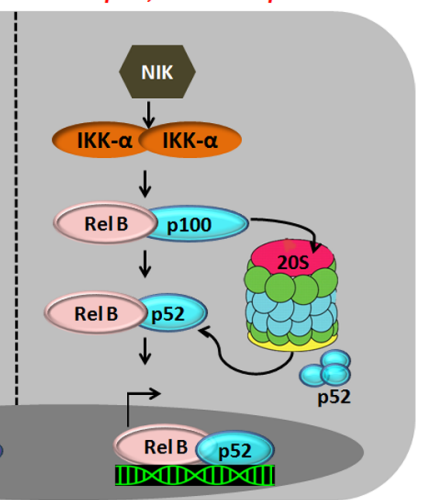

No activation by Tax-2
FIGURE 2 | Illustration of canonical and non-canonical NF-кB pathway activation by HTLV-1 Tax-1 (A) and Tax-2 (B). Canonical NF-kB pathway involves a cascade of phosphorylation events by kinases such as TAK1 and the IKK complex $(\alpha, \beta, \gamma)$ which results in the proteasomal degradation of the cytoplasmic inhibitor $\left(I_{\kappa} B\right)$ and the translocation of the NF- $\mathrm{KB}$ dimers to the nucleus and transcriptional activation. The non-canonical pathway involves the NF-KB-inducing kinase (NIK) and IKK- $\alpha$ subunit $(\alpha)$ and results in the proteasomal degradation of $\mathrm{p} 100$ and the nuclear translocation of NF-kB dimers p52/RelB and activation of gene expression.

(Shoji et al., 2009). To date, there is no evidence of the ability of Tax- 2 to activate the non-canonical NF- $\kappa \mathrm{B}$ pathway. In fact, the transforming activity of Tax-1 in CTLL-2 (cytotoxic T-lymphocyte cell lines) cells constitutively expressing the IL-2 receptor is much higher than Tax-2 and this activity has been shown to be partly mediated through the non-canonical NF-кB pathway (Tsubata et al., 2005; Kondo et al., 2006; Higuchi et al., 2007; Shoji et al., 2009). Within the same line, a constitutively active NIK, restores the transforming activity of Tax-2 to a level equivalent to Tax-1 (Higuchi et al., 2007). This inability of Tax-2 to activate the noncanonical NF- $\kappa \mathrm{B}$ pathway might partially explain its inability to transform T cells and induce ATL development. 


\section{Tax-1 AND Tax-2 P0ST-TRANSLATIONAL MODIFICATIONS}

Post-translational modifications of Tax-1 and Tax-2 proteins have been shown to play a critical role in their cellular localization, transactivation, and protein-protein interactions. Furthermore, Tax-1 and Tax-2 pleotropic effects and their structural organization make these proteins a target of many other potential post-translational events which still need to be discovered.

\section{PHOSPHORYLATION}

To date, six Tax-1 residues were identified as phosphorylation targets: Thr-48, Thr-184, Thr-215, Ser-300, Ser-301, and Ser-336 (Bex et al., 1999; Durkin et al., 2006; Figure 3). Adjacent serine residues at positions 300 and 301 in the carboxy-terminus of Tax represent the major sites for phosphorylation. Indeed, phosphorylation of at least one of these serine residues is required for Tax localization in nuclear bodies and for Tax-mediated activation of gene expression via both the ATF/CREB and NF- $\kappa$ B pathways (Bex et al., 1999). Furthermore, Ser-300 and Ser-301 are required for further posttranslational modifications such as ubiquitylation, SUMOylation, and acetylation (Lodewick et al., 2009). On the other hand, the serine/threonine kinase CK2 phosphorylates Tax-1 at three residues: Ser-336, Ser-344, and Thr-351 within its C-terminus, which indirectly affects NF- $\kappa$ B activation (Higuchi et al., 2007; Bidoia et al., 2010). Some indirect evidence of the involvement of Ser-160 phosphorylation in stabilizing Tax-1 has been recently reported (Jeong et al., 2009). Although Tax-1 and Tax-2 share $85 \%$ homology in their amino acid sequences, and all the phosphorylated residues are conserved except for Ser-336, the phosphorylation status of Tax-2 is still not well determined. In vitro studies showed that CK2 does not phosphorylate Tax-2 as for Tax-1 (Bidoia et al., 2010). A detailed mutational analysis of Tax-2 residues may help in identifying Tax-2 phosphorylated residues and their impact on Tax-2 function.

\section{ACETYLATION}

Tax-1 has been shown to be acetylated at Lys-346 (Lodewick et al., 2009). Acetylated forms of Tax-1 were detected in both Tax-1 transfected 293 T cells and T lymphocytes (Lodewick et al., 2009). In the same study it has been suggested that phosphorylation of Ser-300/Ser-301 is essential for its nuclear translocation and hence is a prerequisite for Tax- 1 acetylation through interaction with p300 (Figure 3). Tax-1 acetylation in turn participates in NF- $\kappa$ B activation (Lodewick et al., 2009). Although there is not much studies yet on Tax-2 acetylation, Lodewick et al. (2009) reported that Tax-2 may also be acetylated.

\section{UBIQUITYLATION AND SUMOylation}

Ubiquitylation and SUMOylation have been shown to play an important role in the cellular localization, function, and proteinprotein interactions of both Tax-1 and Tax-2 (Chiari et al., 2004; Peloponese etal., 2004; Harhaj etal., 2007; Turci et al., 2009; Avesani et al., 2010). Tax-1 has ten lysines (Figure 3). Five of these residues located within Tax-1 C-terminal region were found to be the major targets ubiquitylation [Lys-189 (K4), Lys-197 (K5), Lys263 (K6), Lys-280 (K7), and Lys-284 (K8)], whereas SUMOylation takes place on Lys-280 (K7) and Lys284 (K8) (Lamsoul et al., 2005; Nasr et al., 2006).

Tax-1 is indeed differentially ubiquitylated by either K-48 ubiquitin chains leading to Tax degradation by the proteasome or by K-63 ubiquitin chains that mediates IKK recruitment to the centrosome and IKK activation (Kfoury et al., 2008). On the other hand, Tax-1 SUMOylation is required for nuclear body formation and recruitment of RelA and IKK- $\gamma$ to Tax-1-related nuclear bodies, where Tax-driven transcription is promoted (Lamsoul et al., 2005; Nasr et al., 2006; Harhaj et al., 2007; Kfoury et al., 2011). A RING (Really Interesting New Gene) finger domain containing protein RNF4 has recently been shown to bind putative Tax ubiquitin/SUMO modification sites K280/K284 and increase

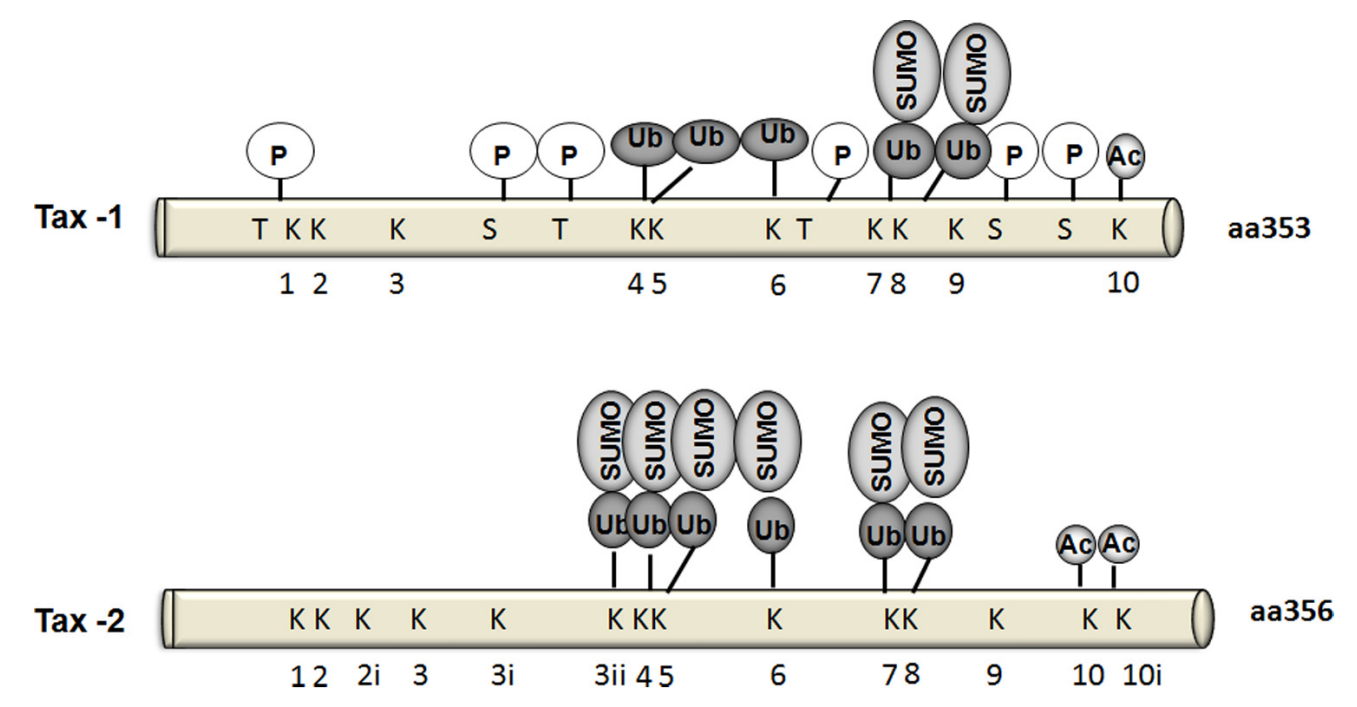

FIGURE 3 | Schematic comparison of Tax-1 and Tax-2 post-translational modifications. Sites of phosphorylation (P), and target lysines for ubiquitylation, SUMOylation, or acetylation are indicated. 
Tax cytoplasmic enrichment and NF- $\kappa \mathrm{B}$ activation (Fryrear et al., 2012). A recent report added new insights to our understanding of Tax-1 and Tax-2 ubiquitylation- and SUMOylation-dependent NF- $\kappa$ B activation. Bonnet et al. (2012) used Tax-1 mutants (TaxP79AQ81A) defective for nuclear body formation. Ubiquitylation levels of the mutant and the wild type protein were similar, however, the endogenous SUMOylation levels were lower in the mutant. Despite low SUMOylation levels in the mutants, NF- $\kappa \mathrm{B}$ activation was not affected enforcing the possibility that low levels of SUMOylation may suffice for Tax-1-induced NF- $\kappa$ B activation.

The involvement of Tax-2 SUMOylation and ubiquitylation in NF- $\kappa \mathrm{B}$ activation remains controversial. Journo et al. (2013) showed that in contrast to Tax-1, Tax-2 SUMOylation and ubiquitylation are not essential to activate NF- $\kappa$. In their study, Tax-2 conjugation to endogenous SUMO and ubiquitin was barely detectable, however, Tax-2 was still acetylated. This low level of conjugation to endogenous ubiquitin and SUMO did not prevent Tax-2 activation of an NF- $\kappa \mathrm{B}$-dependent promoter or its interaction with IKK- $\gamma /$ NEMO. Furthermore, a lysine-less Tax- 2 mutant, which is defective for ubiquitylation and SUMOylation but not acetylation, is still able to transactivate an NF- $\kappa \mathrm{B}$-dependent promoter and bind and activate the IKK complex to induce RelA/p65 nuclear translocation. On the other hand, using transfection methods, Turci et al. (2012) have reported that Tax-1 and Tax-2 share a common mechanism of NF- $\mathrm{BB}$ activation and that both depend on their ubiquitylation and SUMOylation status. Thus, they show that patterns and levels of ubiquitylation between Tax-1 and Tax2 are conserved, except for a reduced representation of the Tax-2 mono-ubiquitylated form compared to Tax-1.

\section{INHIBITION OF APOPTOSIS AND INDUCTION OF DNA DAMAGE BY Tax-1 AND Tax-2}

Induction of programmed cell death by Tax-1 has been shown in many studies using both in vitro Tax-1 inducible cell lines (Ray and Gottlieb, 1993) and in vivo transgenic mice. Indeed, Tax-1 transgenic mice are characterized by enhanced apoptosis which is associated with elevated levels of oncoproteins such as Myc, Fos, Jun, and p53 expression (Hall et al., 1998). It is important to mention that ATL malignant transformation involves complex and multi-step mechanisms such as accumulation of DNA damage and aneuploidy. Furthermore, Tax-1 expression sensitizes cells to apoptotic cell death induced by DNA damaging agents (Kao et al., 2000) and by tumor necrosis factor alpha (TNF- $\alpha$; Saggioro et al.,

\section{REFERENCES}

Adhikari, A., Xu, M., and Chen, Z. J. (2007). Ubiquitin-mediated activation of TAK1 and IKK. Oncogene 26, 3214-3226. doi: 10.1038/sj.onc. 1210413

Adya, N., and Giam, C. Z. (1995). Distinct regions in human T-cell lymphotropic virus type I tax mediate interactions with activator protein CREB and basal transcription factors. J. Virol. 69, 1834-1841.

Adya, N., Zhao, L. J., Huang, W., Boros, I., and Giam, C. Z. (1994).

2001). Upon UV irradiation, Tax-1 localization was increased at the cytoplasm and decreased in the nucleus and Tax-1 NES have been shown to be required for its stress-induced nucleocytoplasmic translocation (Gatza and Marriott, 2006). Caspase activity has been shown to be crucial for Tax-1-induced cell death and apoptosis whereas B cell lymphoma 2 (Bcl-2) expression has been shown to be associated with cell death prevention (Yamada et al., 1994; Chen et al., 1997; Chlichlia et al., 1997, 2002; Rivera-Walsh et al., 2001; Kasai and Jeang, 2004). Interestingly, Tax has been shown by many studies to both induce apoptosis and represses it. Many groups have shown the importance of Tax-1-mediated NF- $\kappa$ B activation in induction of apoptosis (Wheeler et al., 1993; Chen et al., 1997; Chlichlia et al., 1997; Los et al., 1998; RiveraWalsh et al., 2001). Tax mutants defective in NF- $\kappa$ B activation have reduced apoptosis-inducing activities, and inhibition of Taxmediated NF- $\kappa \mathrm{B}$ transactivation partially inhibited apoptotic cell death (Los et al., 1998; Harrod et al., 2000; Rivera-Walsh et al., 2001). Tax also represses the transcription of the proapoptotic bax gene (Brauweiler et al., 1997). In addition, Tax inhibits the caspase cascade in an NF- $\mathrm{B}$-dependent manner through the induction of the caspase inhibitors X-IAP, cIAP-1, and c-IAP-2 (Kelly et al., 1993).

Previous experiments performed on $\mathrm{T}$ cell lines derived from HTLV-2-infected individuals and Tax-2 expressing various cell lines have shown that Tax-2 is capable of inhibiting Fas-mediated apoptosis through the expression of $\mathrm{bcl}-\mathrm{x}(\mathrm{L})$ messenger and protein (Zehender et al., 2001).

\section{CONCLUDING REMARKS}

To date, vast amount of knowledge has been produced regarding the HTLV-1 Tax-1 oncoprotein. Many studies have provided some insights on Tax-1 transcriptional regulation, subcellular localization and post-translational modifications. However, less is known about HTLV-2 Tax-2 although many aspects of its activity and regulation is now being studied. That HTLV-2 is defective in promoting certain steps of leukemogenesis, may indeed serve as a useful comparative tool for understanding the pathogenicity of HTLV-1.

\section{ACKNOWLEDGMENTS}

This work was supported by the American University of Beirut Medical Practice Plan and University Research Board, the Lebanese National Council for Scientific Research, and the Lady TATA Memorial Trust.

Oncogene 14, 2071-2078. doi: 10.1038/sj.onc. 1201045 tion specificity by Tax results from interaction with Ala-Ala-Arg at positions 282-284 near the conserved DNA-binding domain of CREB. Proc. Natl. Acad. Sci. U.S.A. 91, 5642-5646. doi: 10.1073/pnas.91.12. 5642

Akagi, T., Ono, H., Nyunoya, H., and Shimotohno, K. (1997). Characterization of peripheral blood T-lymphocytes transduced with HTLV-I Tax mutants with different trans-activating phenotypes.
Alefantis, T., Barmak, K., Harhaj, E. W., Grant, C., and Wigdahl, B. (2003). Characterization of a nuclear export signal within the human $\mathrm{T}$ cell leukemia virus type I transactivator protein Tax. J. Biol. Chem. 278, 21814-21822. doi: 10.1074/jbc.M211576200

Alefantis, T., Mostoller, K., Jain, P., Harhaj, E., Grant, C., and Wigdahl, B. (2005). Secretion of the human $\mathrm{T}$ cell leukemia virus type I transactivator protein tax. J. Biol. Chem. 280, 17353-17362. doi: 10.1074/jbc.M409851200

Alexandre, C., and Verrier, B. (1991). Four regulatory elements in the human c-fos promoter mediate transactivation by HTLV-1 Tax protein. Oncogene 6, 543-551.

Anderson, M. G., and Dynan, W. S. (1994). Quantitative studies of the effect of HTLV-I Tax protein on CREB protein-DNA binding. Nucleic Acids Res. 22, 3194-3201. doi: 10.1093/nar/22.15.3194 
Ariumi, Y., Kaida, A., Lin, J. Y., Hirota, M., Masui, O., Yamaoka, S., et al. (2000). HTLV-1 tax oncoprotein represses the p53-mediated transactivation function through coactivator CBP sequestration. Oncogene 19, 1491-1499. doi: 10.1038/ sj.onc. 1203450

Arnulf, B., Villemain, A., Nicot, C., Mordelet, E., Charneau, P., Kersual, J., et al. (2002). Human T-cell lymphotropic virus oncoprotein Tax represses TGF-beta 1 signaling in human $\mathrm{T}$ cells via c-Jun activation: a potential mechanism of HTLV-I leukemogenesis. Blood 100, 41294138. doi: 10.1182/blood-2001-120372

Avesani, F., Romanelli, M. G., Turci, M., Di Gennaro, G., Sampaio, C., Bidoia, C., et al. (2010). Association of HTLV Tax proteins with TAK1-binding protein 2 and RelA in calreticulincontaining cytoplasmic structures participates in Tax-mediated NFkappaB activation. Virology 408, 3948. doi: 10.1016/j.virol.2010.08.023

Azran, I., Schavinsky-Khrapunsky, Y., and Aboud, M. (2004). Role of Tax protein in human T-cell leukemia virus type-I leukemogenicity. Retrovirology 1, 20. doi: 10.1186/17424690-1-20

Baeuerle, P. A., and Henkel, T. (1994). Function and activation of NF-kappa $\mathrm{B}$ in the immune system. Annu. Rev. Immunol. 12, 141-179. doi: 10.1146/annurev.iy.12.040194.00104

Baldwin, A. S. Jr. (1996). The NFkappa B and I kappa B proteins: new discoveries and insights. Annu. Rev. Immunol. 14, 649-683. doi: 10.1146/annurev.immunol.12.1.141

Bantignies, F., Rousset, R., Desbois, C., and Jalinot, P. (1996). Genetic characterization of transactivation of the human T-cell leukemia virus type 1 promoter: Binding of Tax to Taxresponsive element 1 is mediated by the cyclic AMP-responsive members of the CREB/ATF family of transcription factors. Mol. Cell. Biol. 16, 2174-2182.

Basbous, J., Bazarbachi, A., Granier, C., Devaux, C., and Mesnard, J. M. (2003). The central region of human T-cell leukemia virus type 1 Tax protein contains distinct domains involved in subunit dimerization. J. Virol. 77, 13028-13035. doi: 10.1128/JVI.77.24.13028-13035.2003

Bellon, M., and Nicot, C. (2008). Central role of PI3K in transcriptional activation of hTERT in HTLV-Iinfected cells. Blood 112, 2946-2955. doi: 10.1182/blood-2008-01-134692

Bertazzoni, U., Turci, M., Avesani, F., Di Gennaro, G., Bidoia, C., and
Romanelli, M. G. (2011). Intracellular localization and cellular factors interaction of HTLV-1 and HTLV-2 Tax proteins: similarities and functional differences. Viruses 3, 541-560. doi: 10.3390/v3050541

Bex, F., Mcdowall, A., Burny, A., and Gaynor, R. (1997). The human T-cell leukemia virus type 1 transactivator protein Tax colocalizes in unique nuclear structures with NF-kappaB proteins. J. Virol. 71, 3484-3497.

Bex, F., Murphy, K., Wattiez, R. Burny, A., and Gaynor, R. B. (1999). Phosphorylation of the human T-cell leukemia virus type 1 transactivator tax on adjacent serine residues is critical for tax activation. J. Virol. 73, 738-745.

Bex, F., Yin, M. J., Burny, A., and Gaynor, R. B. (1998). Differential transcriptional activation by human T-cell leukemia virus type 1 Tax mutants is mediated by distinct interactions with CREB binding protein and p300. Mol. Cell. Biol. 18, 2392 2405.

Bidoia, C., Mazzorana, M., Pagano, M. A., Arrigoni, G., Meggio, F., Pinna, L. A., etal. (2010). The pleiotropic protein kinase CK2 phosphorylates HTLV-1 Tax protein in vitro, targeting its PDZ-binding motif. Virus Genes 41, 149-157. doi: 10.1007/s11262-010-0494-3

Bodor, J., Walker, W., Flemington, E., Spetz, A. L., and Habener, J. F. (1995). Modulation of Tax and PKA-mediated expression of HTLV-I promoter via cAMP response element binding and modulator proteins CREB and CREM. FEBS Lett. 377, 413-418. doi: 10.1016/00145793(95)01299-0

Bonnet, A., Randrianarison-Huetz, V., Nzounza, P., Nedelec, M., Chazal, M. Waast, L., et al. (2012). Low nuclear body formation and tax SUMOylation do not prevent NF-kappaB promoter activation. Retrovirology 9, 77. doi: 10.1186/1742-4690-9-77

Boxus, M., Twizere, J. C., Legros, S., Dewulf, J. F., Kettmann, R., and Willems, L. (2008). The HTLV-1 Tax interactome. Retrovirology 5, 76. doi: 10.1186/1742-4690-5-76

Brauweiler, A., Garl, P., Franklin, A. A., Giebler, H. A., and Nyborg, J. K. (1995). A molecular mechanism for human T-cell leukemia virus latency and Tax transactivation. J. Biol. Chem. 270, 12814-12822. doi: 10.1074/jbc.270.21.12814

Brauweiler, A., Garrus, J. E., Reed, J. C., and Nyborg, J. K. (1997). Repression of bax gene expression by the HTLV-1 Tax protein: implications for suppression of apoptosis in virally infected cells. Virology 231, 135-140. doi: 10.1006/viro.1997.8509

Burton, M., Upadhyaya, C. D., Maier, B., Hope, T. J., and Semmes, O. J. (2000). Human T-cell leukemia virus type 1 Tax shuttles between functionally discrete subcellular targets. J. Virol. 74, 2351-2364. doi: 10.1128/JVI.74.5.2351-2364.2000

Cantley, L. C. (2002). The phosphoinositide 3-kinase pathway. Science 296, 1655-1657. doi: 10.1126/science.296.5573.1655

Cereseto, A., Mulloy, J. C., and Franchini, G. (1996). Insights on the pathogenicity of human Tlymphotropic/leukemia virus types I and II. J. Acquir. Immune Defic. Syndr. Hum. Retrovirol. 13(Suppl. 1), S69-S75. doi: 10.1097/00042560199600001-00013

Chen, X., Zachar, V., Zdravkovic, M., Guo, M., Ebbesen, P., and Liu, X. (1997). Role of the Fas/Fas ligand pathway in apoptotic cell death induced by the human $\mathrm{T}$ cell lymphotropic virus type I Tax transactivator. J. Gen. Virol. 78(Pt 12), 3277-3285.

Cheng, H., Cenciarelli, C., Shao, Z. Vidal, M., Parks, W. P., Pagano, M., et al. (2001). Human T cell leukemia virus type 1 Tax associates with a molecular chaperone complex containing hTid-1 and Hsp70. Curr. Biol. 11, 1771-1775. doi: 10.1016/S09609822(01)00540-1

Chevalier, S. A., Meertens, L., Calattini, S., Gessain, A., Kiemer, L., and Mahieux, R. (2005). Presence of a functional but dispensable nuclear export signal in the HTLV-2 Tax protein. Retrovirology 2, 70. doi: 10.1186/1742-4690-2-70

Chiari, E., Lamsoul, I., Lodewick, J., Chopin, C., Bex, F., and Pique, C. (2004). Stable ubiquitination of human T-cell leukemia virus type 1 tax is required for proteasome binding. J. Virol. 78, 11823-11832. doi: 10.1128/JVI.78.21.11823-11832.2004

Chlichlia, K., Busslinger, M., Peter, M. E., Walczak, H., Krammer, P. H., Schirrmacher, V., et al. (1997). ICE-proteases mediate HTLV-I Taxinduced apoptotic T-cell death. Oncogene 14, 2265-2272. doi: 10.1038/sj.onc. 1201070

Chlichlia, K., and Khazaie, K. (2010). HTLV-1 Tax: linking transformation, DNA damage and apoptotic T-cell death. Chem. Biol. Interact. 188, 359 365. doi: 10.1016/j.cbi.2010.06.005

Chlichlia, K., Los, M., SchulzeOsthoff, K., Gazzolo, L., Schirrmacher, V., and Khazaie, K. (2002). Redox events in HTLV-1 Tax-induced apoptotic T-cell death. Antioxid.
Redox Signal. 4, 471-477. doi: $10.1089 / 15230860260196263$

Chu, Z. L., Didonato, J. A., Hawiger, J., and Ballard, D. W. (1998). The tax oncoprotein of human Tcell leukemia virus type 1 associates with and persistently activates IkappaB kinases containing IKKalpha and IKKbeta. J. Biol. Chem. 273, 1589115894. doi: 10.1074/jbc.273.26.15891 Dejardin, E. (2006). The alternative NFkappaB pathway from biochemistry to biology: pitfalls and promises for future drug development. Biochem. Pharmacol. 72, 1161-1179. doi: 10.1016/j.bcp.2006.08.007

de la Fuente, C., Gupta, M. V., Klase, Z., Strouss, K., Cahan, P., Mccaffery, T., et al. (2006). Involvement of HTLV-I Tax and CREB in aneuploidy: a bioinformatics approach. Retrovirology 3, 43. doi: 10.1186/1742-4690-3-43

Dodon, M. D., Li, Z., Hamaia, S., and Gazzolo, L. (2004). Tax protein of human T-cell leukaemia virus type 1 induces interleukin 17 gene expression in T cells. J. Gen. Virol. 85, 1921-1932. doi: 10.1099/vir.0. 79921-0

Durkin, S. S., Ward, M. D., Fryrear, K. A., and Semmes, O. J. (2006). Site-specific phosphorylation differentiates active from inactive forms of the human T-cell leukemia virus type 1 Tax oncoprotein. J. Biol. Chem. 281, 31705-31712. doi: 10.1074/jbc.M607011200

Endo, K., Hirata, A., Iwai, K., Sakurai, M., Fukushi, M., Oie, M., et al. (2002). Human T-cell leukemia virus type 2 (HTLV-2) Tax protein transforms a rat fibroblast cell line but less efficiently than HTLV1 Tax. J. Virol. 76, 2648-2653. doi: 10.1128/JVI.76.6.2648-2653.2002

Fanning, A. S., and Anderson, J. M. (1999). Protein modules as organizers of membrane structure. Curr. Opin. Cell Biol. 11, 432-439. doi: 10.1016/S0955-0674(99)80062-3

Feuer, G., and Green, P. L. (2005). Comparative biology of human T-cell lymphotropic virus type 1 (HTLV-1) and HTLV-2. Oncogene 24, 59966004. doi: 10.1038/sj.onc. 1208971

Franklin, A. A., Kubik, M. F., Uittenbogaard, M. N., Brauweiler, A., Utaisincharoen, P., Matthews, M. A., et al. (1993). Transactivation by the human T-cell leukemia virus Tax protein is mediated through enhanced binding of activating transcription factor-2 (ATF-2) ATF-2 response and cAMP element-binding protein (CREB). J. Biol. Chem. 268, 2122521231.

Fryrear, K. A., Guo, X., Kerscher, O., and Semmes, O. J. (2012). The 
Sumo-targeted ubiquitin ligase RNF4 regulates the localization and function of the HTLV-1 oncoprotein Tax. Blood 119, 1173-1181. doi: 10.1182/blood-2011-06-358564

Fukuda, R., Hayashi, A., Utsunomiya, A., Nukada, Y., Fukui, R., Itoh, K., et al. (2005). Alteration of phosphatidylinositol 3-kinase cascade in the multilobulated nuclear formation of adult $\mathrm{T}$ cell leukemia/lymphoma (ATLL). Proc. Natl. Acad. Sci. U.S.A. 102, 15213-15218. doi: 10.1073/ pnas.0507184102

Gallo, R. C. (1981). Growth of human normal and leukemic T cells: T-cell growth factor (TCGF) and the isolation of a new class of RNA tumor viruses (HTLV). Blood Cells 7, 313329.

Gallo, R. C., Sarngadharan, M. G., Popovic, M., Shaw, G. M., Hahn, B., Wong-Staal, F., et al. (1986). HTLVIII and the etiology of AIDS. Prog. Allergy 37, 1-45.

Gatza, M. L., and Marriott, S. J. (2006). Genotoxic stress and cellular stress alter the subcellular distribution of human T-cell leukemia virus type 1 tax through a CRM1-dependent mechanism. J. Virol. 80, 6657-6668. doi: 10.1128/JVI.02270-05

Gazzard, B. G., Shanson, D. C., Farthing, C., Lawrence, A. G., Tedder, R. S., Cheingsong-Popov, R., et al. (1984). Clinical findings and serological evidence of HTLV-III infection in homosexual contacts of patients with AIDS and persistent generalised lymphadenopathy in London. Lancet 2, 480-483. doi: 10.1016/S01406736(84)92563-7

Geiger, T. R., Sharma, N., Kim, Y. M., and Nyborg, J. K. (2008). The human $\mathrm{T}$-cell leukemia virus type 1 tax protein confers $\mathrm{CBP} / \mathrm{p} 300$ recruitment and transcriptional activation properties to phosphorylated CREB. Mol. Cell. Biol. 28, 1383-1392. doi: 10.1128/MCB.01657-07

Gessain, A., Francis, H., Sonan, T., Giordano, C., Akani, F., Piquemal, M., et al. (1986). HTLV-I and tropical spastic paraparesis in Africa. Lancet 2, 698. doi: 10.1016/S01406736(86)90218-7

Gessain, A., Herve, V., Jeannel, D., Garin, B., Mathiot, C., and De-The, G. (1993). HTLV-1 but not HTLV2 found in pygmies from Central African Republic. J. Acquir. Immune Defic. Syndr. 6, 1373-1374.

Gessain, A., and Mahieux, R. (2000). [Epidemiology, origin and genetic diversity of HTLV-1 retrovirus and STLV-1 simian affiliated retrovirus]. Bull. Soc. Pathol. Exot. 93, 163-171.
Ghosh, S., and Hayden, M. S. (2008). New regulators of NF-kappaB in inflammation. Nat. Rev. Immunol. 8 , 837-848. doi: 10.1038/nri2423

Giebler, H. A., Loring, J. E., Van Orden, K., Colgin, M. A., Garrus, J. E., Escudero, K. W., et al. (1997). Anchoring of CREB binding protein to the human T-cell leukemia virus type 1 promoter: a molecular mechanism of Tax transactivation. Mol. Cell. Biol. 17, 5156-5164.

Gitlin, S. D., Lindholm, P. F., Marriott, S. J., and Brady, J. N. (1991). Transdominant human T-cell lymphotropic virus type I TAX1 mutant that fails to localize to the nucleus. J. Virol. 65, 2612-2621.

Gohda, J., Irisawa, M., Tanaka Y., Sato, S., Ohtani, K., Fujisawa, J., et al. (2007). HTLV-1 Tax-induced NFkappaB activation is independent of Lys-63-linked-type polyubiquitination. Biochem. Biophys. Res. Commun. 357, 225-230. doi: 10.1016/j.bbrc.2007.03.125

Goubau, P., Carton, H., Kazadi, K., Muya, K. W., and Desmyter, J. (1990). HTLV seroepidemiology in a central African population with high incidence of tropical spastic paraparesis. Trans. R. Soc. Trop. Med. Hyg. 84, 577-579. doi: 10.1016/00359203(90)90046-H

Grassmann, R., Aboud, M., and Jeang, K. T. (2005). Molecular mechanisms of cellular transformation by HTLV1 Tax. Oncogene 24, 5976-5985. doi: 10.1038/sj.onc. 1208978

Hai, T., and Hartman, M. G. (2001). The molecular biology and nomenclature of the activating transcription factor/cAMP responsive element binding family of transcription factors: activating transcription factor proteins and homeostasis. Gene $273,1-11$. doi: 10.1016/S03781119(01)00551-0

Hall, A. P., Irvine, J., Blyth, K., Cameron, E. R., Onions, D. E., and Campbell, M. E. (1998). Tumours derived from HTLV-I tax transgenic mice are characterized by enhanced levels of apoptosis and oncogene expression. J. Pathol. 186, 209-214. doi: 10.1002/(SICI)10969896(1998100) 186:2

Harhaj, E. W., and Sun, S. C. (1999). IKKgamma serves as a docking subunit of the IkappaB kinase (IKK) and mediates interaction of IKK with the human T-cell leukemia virus Tax protein. J. Biol. Chem. 274, 2291122914. doi: 10.1074/jbc.274.33. 22911

Harhaj, N. S., Sun, S. C., and Harhaj, E. W. (2007). Activation of NF-kappa $\mathrm{B}$ by the human $\mathrm{T}$ cell leukemia virus type I Tax oncoprotein is associated with ubiquitin-dependent relocalization of I kappa B kinase. J. Biol. Chem. 282, 4185-4192. doi: 10.1074/jbc.M611031200

Harris, B. Z., and Lim, W. A. (2001). Mechanism and role of PDZ domains in signaling complex assembly. J. Cell Sci. 114, 3219-3231.

Harrod, R., Kuo, Y. L., Tang, Y., Yao, Y., Vassilev, A., Nakatani, Y., et al. (2000). p300 and p300/cAMPresponsive element-binding protein associated factor interact with human T-cell lymphotropic virus type-1 Tax in a multi-histone acetyltransferase/activator-enhancer complex. $J$. Biol. Chem. 275, 11852-11857. doi: 10.1074/jbc.275.16.11852

Hasegawa, H., Sawa, H., Lewis, M. J., Orba, Y., Sheehy, N., Yamamoto, Y., et al. (2006). Thymus-derived leukemia-lymphoma in mice transgenic for the Tax gene of human Tlymphotropic virus type I. Nat. Med. 12, 466-472. doi: 10.1038/nm1389

Heneine, W., Kaplan, J. E., Gracia, F., Lal, R., Roberts, B., Levine, P. H., et al. (1991). HTLV-II endemicity among Guaymi Indians in Panama. N. Engl. J. Med. 324, 565. doi: 10.1056/NEJM199102213240815

Higuchi, M., and Fujii, M. (2009). Distinct functions of HTLV-1 Tax1 from HTLV-2 Tax2 contribute key roles to viral pathogenesis. Retrovirology 6, 117. doi: 10.1186/1742-4690-6-117

Higuchi, M., Tsubata, C., Kondo, R. Yoshida, S., Takahashi, M., Oie, M., etal. (2007). Cooperation of NF-kappaB2/p100 activation and the PDZ domain binding motif signal in human T-cell leukemia virus type 1 (HTLV-1) Taxl but not HTLV 2 Tax2 is crucial for interleukin-2independent growth transformation of a T-cell line. J. Virol. 81, 11900 11907. doi: 10.1128/JVI.00532-07

Hinuma, Y. (1982). [Virological study of adult T-cell leukemia]. Nihon Rinsho 40, 2531-2539.

Hinuma, Y., Gotoh, Y., Sugamura, K., Nagata, K., Goto, T., Nakai, M., et al. (1982). A retrovirus associated with human adult T-cell leukemia: in vitro activation. Gann 73, 341-344.

Hirai, H., Suzuki, T., Fujisawa, J., Inoue, J., and Yoshida, M. (1994). Tax protein of human T-cell leukemia virus type I binds to the ankyrin motifs of inhibitory factor kappa $\mathrm{B}$ and induces nuclear translocation of transcription factor NF-kappa B proteins for transcriptional activation. Proc. Natl. Acad. Sci. U.S.A. 91, 3584-3588. doi: 10.1073/pnas.91.9.3584

Hirata, A., Higuchi, M., Niinuma, A. Ohashi, M., Fukushi, M., Oie, M., et al. (2004). PDZ domain-binding motif of human T-cell leukemia virus type 1 Tax oncoprotein augments the transforming activity in a rat fibroblast cell line. Virology 318, 327-336. doi: 10.1016/j.virol.2003.10.006

Hjelle, B., Mills, R., Mertz, G., and Swenson, S. (1990). Transmission of HTLV-II via blood transfusion. Vox Sang. 59, 119-122. doi: 10.1111/j.1423-0410.1990.tb05023.x Igakura, T., Stinchcombe, J. C., Goon, P. K., Taylor, G. P., Weber, J. N., Griffiths, G. M., et al. (2003). Spread of HTLV-I between lymphocytes by virus-induced polarization of the cytoskeleton. Science 299, 17131716. doi: 10.1126/science. 1080115

Ishioka, K., Higuchi, M., Takahashi, M., Yoshida, S., Oie, M., Tanaka, Y., et al. (2006). Inactivation of tumor suppressor Dlg1 augments transformation of a T-cell line induced by human T-cell leukemia virus type 1 Tax protein. Retrovirology 3, 71. doi: 10.1186/1742-4690-3-71

Israel, A. (2010). The Ikk complex, a central regulator of NF-kappaB activation. Cold Spring Harb. Perspect. Biol. 2, a000158. doi: 10.1101/cshperspect.a000158

Jaffe, A. B., and Hall, A. (2005). Rho GTPases: biochemistry and biology. Annu. Rev. Cell Dev. Biol. 21, 247269. doi: 10.1146/annurev.cellbio. 21.020604.150721

Jain, P., Mostoller, K., Flaig, K. E., Ahuja, J., Lepoutre, V., Alefantis, T., et al. (2007). Identification of human T cell leukemia virus type 1 tax amino acid signals and cellular factors involved in secretion of the viral oncoprotein. J. Biol. Chem. 282, 34581-34593. doi: 10.1074/jbc.M707317200

Jeang, K. T., Boros, I., Brady, J., Radonovich, M., and Khoury, G. (1988). Characterization of cellular factors that interact with the human T-cell leukemia virus type I p40xresponsive 21-base-pair sequence. $J$. Virol. 62, 4499-4509.

Jeang, K. T., Giam, C. Z., Majone, F., and Aboud, M. (2004). Life, death, and tax: role of HTLV-I oncoprotein in genetic instability and cellular transformation. J. Biol. Chem. 279, 3199131994. doi: 10.1074/jbc.R400009200 Jeong, S. J., Dasgupta, A., Jung, K. J., Um, J. H., Burke, A., Park, H. U., etal. (2008). PI3K/AKT inhibition induces caspase-dependent apoptosis in HTLV-1-transformed cells. Virology 370, 264-272. doi: 10.1016/j.virol.2007.09.003

Jeong, S. J., Pise-Masison, C. A., Radonovich, M. F., Park, H. U., and Brady, J. N. (2005). A novel NFkappaB pathway involving IKKbeta 
and p65/RelA Ser-536 phosphorylation results in p53 Inhibition in the absence of NF-kappaB transcriptional activity. J. Biol. Chem. 280, 10326-10332. doi: 10.1074/jbc. M412643200

Jeong, S. J., Radonovich, M., Brady, J. N., and Pise-Masison, C. A. (2004). HTLV-I Tax induces a novel interaction between p65/RelA and p53 that results in inhibition of p53 transcriptional activity. Blood 104, 1490-1497. doi: 10.1182/blood-2003-12-4174

Jeong, S. J., Ryo, A., and Yamamoto, N. (2009). The prolyl isomerase Pinl stabilizes the human T-cell leukemia virus type 1 (HTLV-1) Tax oncoprotein and promotes malignant transformation. Biochem. Biophys. Res. Commun. 381, 294-299. doi: 10.1016/j.bbrc.2009.02.024

Jin, D. Y., Giordano, V., Kibler, K. V., Nakano, H., and Jeang, K. T. (1999). Role of adapter function in oncoprotein-mediated activation of NF-kappaB. Human T-cell leukemia virus type I Tax interacts directly with IkappaB kinase gamma. J. Biol. Chem. 274, 17402-17405. doi: 10.1074/jbc.274.25.17402

Jin,D.Y.,andJeang, K. T. (1997). HTLV-I Tax self-association in optimal transactivation function. NucleicAcidsRes. 25,379-387.doi:10.1093/nar/25.2.379

Journo, C., Bonnet, A., Favre-Bonvin, A., Turpin, J., Vinera, J., Cote, E. et al. (2013). Human T cell leukemia virus type 2 tax-mediated NF-kappaB activation involves a mechanism independent of Tax conjugation to ubiquitin and SUMO. J. Virol. 87, 1123-1136. doi: 10.1128/JVI.0179212

Journo, C., Douceron, E., and Mahieux, R. (2009). HTLV gene regulation: because size matters, transcription is not enough. Future Microbiol. 4 425-440. doi: 10.2217/fmb.09.13

Kalyanaraman, V. S., Sarngadharan, M. G., Robert-Guroff, M., Miyoshi, I., Golde, D., and Gallo, R. C. (1982). A new subtype of human T-cell leukemia virus (HTLV-II) associated with a T-cell variant of hairy cell leukemia. Science 218, 571-573. doi: 10.1126/science.6981847

Kao, S. Y., Lemoine, F. J., and Mariott, S. J. (2000). HTLV-1 Tax protein sensitizes cells to apoptotic cell death induced by DNA damaging agents. Oncogene 19, 2240-2248. doi: 10.1038/sj.onc.1203559

Kaplan, J. E., Khabbaz, R. F., Murphy, E. L., Hermansen, S., Roberts, C., Lal, R., et al. (1996). Male-to-female transmission of human T-cell lymphotropic virus types I and II: association with viral load. The Retrovirus
Epidemiology Donor Study Group. J. Acquir. Immune Defic. Syndr. Hum. Retrovirol. 12, 193-201. doi: 10.1097/00042560-199606010-00014

Karin, M., and Ben-Neriah, Y. (2000). Phosphorylation meets ubiquitination: the control of NF-[kappa]B activity. Annu. Rev. Immunol. 18, 621-663. doi: 10.1146/annurev. immunol.18.1.621

Kasai, T., and Jeang, K. T. (2004). Two discrete events, human T-cell leukemia virus type I Tax oncoprotein expression and a separate stress stimulus, are required for induction of apoptosis in T-cells. Retrovirology 1, 7. doi: 10.1186/1742-4690-1-7

Kashanchi, F., and Brady, J. N. (2005). Transcriptional and posttranscriptional gene regulation of HTLV-1. Oncogene 24, 5938-5951. doi: 10.1038/si.onc. 1208973

Kelly, S. L., Lamb, D. C., Baldwin, B. C., and Kelly, D. E. (1993). Benzo(a)pyrene hydroxylase activity in yeast is mediated by $\mathrm{P} 450$ other than sterol 14 alpha-demethylase. Biochem. Biophys. Res. Com mun. 197, 428-432. doi: 10.1006/ bbrc. 1993.2497

Kfoury, Y., Nasr, R., Favre-Bonvin, A., El-Sabban, M., Renault, N., Giron, M. L., et al. (2008). Ubiquitylated Tax targets and binds the IKK signalosome at the centrosome. Oncogene 27, 1665-1676. doi: 10.1038/sj.onc. 1210804

Kfoury, Y., Nasr, R., Hermine, O., De The, H., and Bazarbachi, A. (2005). Proapoptotic regimes for HTLV-Itransformed cells: targeting Tax and the NF-kappaB pathway. Cell Death Differ. 12(Suppl. 1), 871-877. doi: 10.1038/sj.cdd.4401624

Kfoury, Y., Setterblad, N., El-Sabban, M., Zamborlini, A., Dassouki, Z., El Hajj, H., et al. (2011). Tax ubiquitylation and SUMOylation control the dynamic shuttling of Tax and NEMO between Ubc9 nuclear bodies and the centrosome. Blood 117, 190-199. doi: 10.1182/blood-2010-05-285742

Khabbaz, R. F., Hartel, D., Lairmore, M. Horsburgh, C. R., Schoenbaum, E. E., Roberts, B., et al. (1991). Human T lymphotropic virus type II (HTLVII) infection in a cohort of New York intravenous drug users: an old infection? J. Infect. Dis. 163, 252-256. doi: 10.1093/infdis/163.2.252

Kibler, K. V., and Jeang, K. T. (2001) CREB/ATF-dependent repression of cyclin a by human T-cell leukemia virus type 1 Tax protein. J. Virol. 75, 2161-2173. doi: 10.1128/JVI.75.5.2161-2173.2001

Kim, S. J., Kehrl, J. H., Burton, J., Tendler, C. L., Jeang, K. T.,
Danielpour, D., et al. (1990). Transactivation of the transforming growth factor beta 1 (TGF-beta 1) gene by human $\mathrm{T}$ lymphotropic virus type 1 tax: a potential mechanism for the increased production of TGFbeta 1 in adult $\mathrm{T}$ cell leukemia. J. Exp. Med. 172, 121-129. doi: 10.1084/jem.172.1.121

Kondo, R., Higuchi, M., Takahashi, M., Oie, M., Tanaka, Y., Gejyo, F. et al. (2006). Human T-cell leukemia virus type 2 Tax protein induces interleukin 2-independent growth in a T-cell line. Retrovirology 3, 88. doi: 10.1186/1742-4690-3-88

Lairmore, M. D., Jacobson, S., Gracia, F., De, B. K., Castillo, L., Larreategui, M., et al. (1990). Isolation of human T-cell lymphotropic virus type 2 from Guaymi Indians in Panama. Proc. Natl. Acad. Sci. U.S.A. 87, 8840-8844. doi: $10.1073 /$ pnas.87.22.8840

Lamsoul, I., Lodewick, J., Lebrun, S., Brasseur, R., Burny, A., Gaynor, R. B., et al. (2005). Exclusive ubiquitination and sumoylation on overlapping lysine residues mediate NF-kappaB activation by the human T-cell leukemia virus tax oncoprotein. $\mathrm{Mol}$. Cell. Biol. 25, 10391-10406. doi: 10.1128/MCB.25.23.10391-10406. 2005

Landry, S., Halin, M., Lefort, S., Audet, B., Vaquero, C., Mesnard, J. M. et al. (2007). Detection, characterization, and regulation of antisense transcripts in HIV-1. Retrovirology 4, 71. doi: 10.1186/1742-4690-4-71

Lee, D. K., Kim, B. C., Brady, J. N., Jeang, K. T., and Kim, S. J. (2002). Human T-cell lymphotropic virus type 1 tax inhibits transforming growth factor-beta signaling by blocking the association of Smad proteins with Smad-binding element. $J$. Biol. Chem. 277, 33766-33775. doi: 10.1074/jbc.M200150200

Levine, P. H., Jacobson, S., Elliott, R. Cavallero, A., Colclough, G., Dorry, C., etal. (1993). HTLV-II infection in Florida Indians. AIDS Res. Hum. Retroviruses 9, 123-127. doi: 10.1089/aid.1993.9.123

Lodewick, J., Lamsoul, I., Polania, A., Lebrun, S., Burny, A., Ratner, L., et al. (2009). Acetylation of the human T-cell leukemia virus type 1 Tax oncoprotein by $\mathrm{p} 300$ promotes activation of the NF-kappaB pathway. Virology 386, 68-78. doi: 10.1016/j.virol.2008.12.043

Los, M., Khazaie, K., Schulze-Osthoff, K., Baeuerle, P. A., Schirrmacher, V., and Chlichlia, K. (1998). Human $\mathrm{T}$ cell leukemia virus-I (HTLVI) Tax-mediated apoptosis in activated $\mathrm{T}$ cells requires an enhanced intracellular prooxidant state. J. Immunol. 161, 3050-3055.

Mahieux, R., and Gessain, A. (2005). [New human retroviruses: HTLV-3 and HTLV-4]. Med. Trop. (Mars.) 65, 525-528.

Mahieux, R., and Gessain, A. (2007). Adult T-cell leukemia/lymphoma and HTLV-1. Curr. Hematol. Malig. Rep. 2, 257-264. doi: 10.1007/s11899-0070035-x

Mahieux, R., and Gessain, A. (2009). The human HTLV-3 and HTLV4 retroviruses: new members of the HTLV family. Pathol. Biol. (Paris) 57, 161-166. doi: 10.1016/ j.patbio.2008.02.015

Mahieux, R., Pise-Masison, C. A., Lambert, P. F., Nicot, C., De Marchis, L., Gessain, A., et al. (2000a). Differences in the ability of human T-cell lymphotropic virus type 1 (HTLV1) and HTLV-2 tax to inhibit p53 function. J. Virol. 74, 6866-6874. doi: $\quad 10.1128 /$ JVI.74.15.6866-6874. 2000

Mahieux, R., Pise-Masison, C. A., Nicot, C., Green, P., Hall, W. W., and Brady, J. N. (2000b). Inactivation of p53 by HTLV type 1 and HTLV type 2 Tax trans-activators. AIDS Res. Hum. Retroviruses 16, 1677-1681. doi: 10.1089/08892220050193137

Majone, F., Semmes, O. J., and Jeang, K. T. (1993). Induction of micronuclei by HTLV-I Tax: a cellular assay for function. Virology 193, 456-459. doi: 10.1006/viro.1993.1145

Matsuoka, M., and Green, P. L. (2009). The HBZ gene, a key player in HTLV1 pathogenesis. Retrovirology 6, 71 . doi: 10.1186/1742-4690-6-71

Matsuoka, M., and Jeang, K. T. (2007). Human T-cell leukaemia virus type 1 (HTLV-1) infectivity and cellular transformation. Nat. Rev. Cancer 7, 270-280. doi: 10.1038/nrc2111

Mccabe, A., Hashimoto, K., Hall, W. W., and Sheehy, N. (2013). The Four and a half LIM family are novel interactants of the HTLV-1 oncoprotein Tax1. J. Virol. 87, 7435-7444. doi: 10.1128/JVI.00070-13

Meertens, L., Chevalier, S., Weil, R., Gessain, A., and Mahieux, R. (2004). A 10-amino acid domain within human T-cell leukemia virus type 1 and type 2 tax protein sequences is responsible for their divergent subcellular distribution. J. Biol. Chem. 279, 4330743320. doi: 10.1074/jbc.M400497200 Mori, N., Morishita, M., Tsukazaki, T., Giam, C. Z., Kumatori, A., Tanaka, Y., et al. (2001). Human T-cell leukemia virus type I oncoprotein Tax represses Smad-dependent transforming growth factor beta signaling through interaction with CREB-binding 
protein/p300. Blood 97, 2137-2144. doi: 10.1182/blood.V97.7.2137

Mulloy, J. C., Kislyakova, T., Cereseto, A., Casareto, L., Lomonico, A., Fullen, J., et al. (1998). Human T-cell lymphotropic/leukemia virus type 1 Tax abrogates p53-induced cell cycle arrest and apoptosis through its CREB/ATF functional domain. $J$. Virol. 72, 8852-8860.

Nasr, R., Chiari, E., El-Sabban, M., Mahieux, R., Kfoury, Y., Abdulhay, M., et al. (2006). Tax ubiquitylation and sumoylation control critical cytoplasmic and nuclear steps of NF-kappaB activation. Blood 107, 4021-4029. doi: 10.1182/blood2005-09-3572

Nejmeddine, M., Barnard, A. L., Tanaka, Y., Taylor, G. P., and Bangham, C. R. (2005). Human T-lymphotropic virus, type 1 , tax protein triggers microtubule reorientation in the virological synapse. $J$. Biol. Chem. 280, 29653-29660. doi: 10.1074/jbc.M502639200

Nejmeddine, M., Negi, V. S., Mukherjee, S., Tanaka, Y., Orth, K., Taylor, G. P., et al. (2009). HTLV-1-Tax and ICAM-1 act on T-cell signal pathways to polarize the microtubuleorganizing center at the virological synapse. Blood 114, 1016-1025. doi: 10.1182/blood-2008-03-136770

Nicot, C., Opavsky, R., Mahieux, R., Johnson, J. M., Brady, J. N., Wolff, L., etal. (2000). Tax oncoprotein trans-represses endogenous B-myb promoter activity in human T cells. AIDS Res. Hum. Retroviruses 16, 1629-1632. doi: 10.1089/ 08892220050193065

Nicot, C., Tie, F., and Giam, C. Z. (1998). Cytoplasmic forms of human T-cell leukemia virus type 1 Tax induce NF-kappaB activation. J. Virol. 72, 6777-6784.

Ohshima, K. (2007). Pathological features of diseases associated with human T-cell leukemia virus type I. Cancer Sci. 98, 772-778. doi: 10.1111/j.1349-7006.2007.00456.x

Oteiza, A., and Mechti, N. (2011). The human T-cell leukemia virus type 1 oncoprotein tax controls forkhead box $\mathrm{O} 4$ activity through degradation by the proteasome. J. Virol. 85, 6480 6491. doi: 10.1128/JVI.00036-11

Peloponese, J. M. Jr., Iha, H., Yedavalli, V. R., Miyazato, A., Li, Y., Haller, K., etal. (2004). Ubiquitination of human T-cell leukemia virus type 1 tax modulates its activity. J. Virol. 78, 11686-11695. doi: 10.1128/JVI.78.21.11686-11695.2004

Peloponese, J. M. Jr., and Jeang, K. T. (2006). Role for Akt/protein kinase $\mathrm{B}$ and activator protein-1 in cellular proliferation induced by the human T-cell leukemia virus type 1 tax oncoprotein. J. Biol. Chem. 281, 89278938. doi: 10.1074/jbc.M510598200

Peloponese, J. M. Jr., Kinjo, T., and Jeang, K. T. (2007). Human T-cel leukemia virus type 1 Tax and cellular transformation. Int. J. Hematol. 86 101-106. doi: 10.1532/IJH97.07087

Pennison, M., and Pasche, B. (2007). Targeting transforming growth factor-beta signaling. Curr Opin. Oncol. 19, 579-585. doi: 10.1097/CCO.0b013e3282f0ad0e

Perkins, N. D. (2007). Integrating cellsignalling pathways with NF-kappaB and IKK function. Nat. Rev. Mol. Cell Biol. 8, 49-62. doi: 10.1038/ nrm2083

Pimienta, G., and Pascual, J. (2007). Canonical and alternative MAPK signaling. Cell Cycle 6, 2628-2632. doi: 10.4161/cc.6.21.4930

Pise-Masison, C. A., Mahieux, R., Jiang, H., Ashcroft, M., Radonovich, M. Duvall, J., et al. (2000). Inactivation of p53 by human T-cell lymphotropic virus type 1 Tax requires activation of the NF-kappaB pathway and is dependent on p53 phosphorylation. Mol. Cell. Biol. 20, 3377-3386. doi: 10.1128/MCB.20.10.3377-3386.2000

Poiesz, B. J., Ruscetti, F. W., Gazdar A. F., Bunn, P. A., Minna, J. D. and Gallo, R. C. (1980a). Detection and isolation of type $\mathrm{C}$ retrovirus particles from fresh and cultured lymphocytes of a patient with cutaneous T-cell lymphoma. Proc. Natl. Acad. Sci. U.S.A. 77, 7415-7419. doi: 10.1073/pnas.77.12.7415

Poiesz, B. J., Ruscetti, F. W., Mier, J. W., Woods, A. M., and Gallo, R. C. (1980b). T-cell lines established from human T-lymphocytic neoplasias by direct response to $\mathrm{T}$ cell growth factor. Proc. Natl. Acad. Sci. U.S.A. 77, 6815-6819. doi: 10.1073/pnas.77.11.6815

Ray, W. J., and Gottlieb, D. I. (1993). Expression of ionotropic glutamate receptor genes by P19 embryonal carcinoma cells. Biochem. Biophys. Res. Commun. 197, 1475-1482. doi: 10.1006/bbrc.1993.2643

Reddy, T. R., Li, X., Jones, Y., Ellisman, M. H., Ching, G. Y., Liem, R. K., et al. (1998). Specific interaction of HTLV tax protein and a human type IV neuronal intermediate filament protein. Proc. Natl. Acad. Sci. U.S.A. 95 702-707. doi: 10.1073/pnas.95.2.702

Reddy, T. R., Tang, H., Li, X., and WongStaal, F. (1997). Functional interaction of the HTLV-1 transactivator Tax with activating transcription factor4 (ATF4). Oncogene 14, 2785-2792. doi: 10.1038/sj.onc. 1201119
Ren, T., Dong, W., Takahashi, Y., Xiang, D., Yuan, Y., Liu, X., et al. (2012). HTLV-2 Tax immortalizes human $\mathrm{CD}^{+}$memory $\mathrm{T}$ lymphocytes by oncogenic activation and dysregulation of autophagy. $J$. Biol. Chem. 287, 34683-34693. doi: 10.1074/jbc.M112.377143

Rivera-Walsh, I., Waterfield, M., Xiao, G., Fong, A., and Sun, S. C. (2001). NF-kappaB signaling pathway governs TRAIL gene expression and human T-cell leukemia virus-I Tax-induced T-cell death. J. Biol. Chem. 276, 40385-40388. doi: 10.1074/jbc.C100501200

Ross, T. M., Minella, A. C., Fang, Z. Y., Pettiford, S. M., and Green, P. L. (1997). Mutational analysis of human T-cell leukemia virus type 2 Tax. J. Virol. 71, 8912-8917.

Roucoux, D. F., and Murphy, E. L. (2004). The epidemiology and disease outcomes of human $\mathrm{T}$ lymphotropic virus type II. AIDS Rev. 6, 144-154.

Rousset, R., Desbois, C., Bantignies, F., and Jalinot, P. (1996). Effects on NF-kappa B1/p105 processing of the interaction between the HTLV-1 transactivator Tax and the proteasome. Nature 381, 328-331. doi: 10.1038/381328a0

Rousset, R., Fabre, S., Desbois, C. Bantignies, F., and Jalinot, P. (1998). The C-terminus of the HTLV-1 Tax oncoprotein mediates interaction with the PDZ domain of cellular proteins. Oncogene 16, 643-654. doi 10.1038/sj.onc. 1201567

Ryseck, R. P., Bull, P., Takamiya, M., Bours, V., Siebenlist, U., Dobrzanski, P., et al. (1992). RelB, a new Rel family transcription activator that can interact with p50-NF-kappa B. Mol. Cell. Biol. 12, 674-684.

Saggioro, D., Barp, S., and ChiecoBianchi, L. (2001). Block of a mitochondrial-mediated apoptotic pathway in Tax-expressing murine fibroblasts. Exp. Cell Res. 269, 245 255. doi: 10.1006/excr.2001.5310

Semmes, O. J., and Jeang, K. T. (1992). Mutational analysis of human T-cell leukemia virus type I Tax: regions necessary for function determined with 47 mutant proteins. J. Virol. 66, 7183-7192.

Semmes, O. J., and Jeang, K. T. (1996). Localization of human T-cell leukemia virus type 1 tax to subnuclear compartments that overlap with interchromatin speckles. J. Virol. 70, 6347-6357.

Sheehy, N., Lillis, L., Watters, K., Lewis, M., Gautier, V., and Hall, W. (2006). Functional analysis of human $\mathrm{T}$ lymphotropic virus type 2
Tax proteins. Retrovirology 3, 20. doi: 10.1186/1742-4690-3-20

Sheng, M., and Sala, C. (2001). PDZ domains and the organization of supramolecular complexes. Annu. Rev. Neurosci. 24, 1-29. doi: 10.1146/annurev.neuro.24.1.1

Shoji, T., Higuchi, M., Kondo, R., Takahashi, M., Oie, M., Tanaka, Y., et al. (2009). Identification of a novel motif responsible for the distinctive transforming activity of human T-cell leukemia virus (HTLV) type 1 Tax 1 protein from HTLV-2 Tax2. Retrovirology 6, 83. doi: 10.1186/1742-46906-83

Siebenlist, U., Franzoso, G., and Brown, K. (1994). Structure, regulation and function of NF-kappa B. Annu. Rev. Cell Biol. 10, 405-455. doi: 10.1146/annurev.cellbio.10.1.405

Sieburg, M., Tripp, A., Ma, J. W., and Feuer, G. (2004). Human Tcell leukemia virus type 1 (HTLV-1) and HTLV-2 tax oncoproteins modulate cell cycle progression and apoptosis. J. Virol. 78, 10399-10409. doi: 10.1128/JVI.78.19.10399-10409. 2004

Silverman, N., and Maniatis, T. (2001). NF-kappaB signaling pathways in mammalian and insect innate immunity. Genes Dev. 15, 2321-2342. doi: 10.1101/gad.909001

Smith, M. R., and Greene, W. C. (1990). Identification of HTLV-I tax trans-activator mutants exhibiting novel transcriptional phenotypes. Genes Dev. 4, 1875-1885. doi: 10.1101/gad.4.11.1875

Smith, M. R., and Greene, W. C. (1992). Characterization of a novel nuclear localization signal in the HTLV-I tax transactivator protein. Virology 187, 316-320. doi: 10.1016/00426822(92)90320-O

Suzuki, T., Hirai, H., Murakami, T., and Yoshida, M. (1995). Tax protein of HTLV-1 destabilizes the complexes of NF-kappa B and I kappa B-alpha and induces nuclear translocation of NF-kappa B for transcriptional activation. Oncogene 10, 1199-1207.

Suzuki, T., Ohsugi, Y., Uchida-Toita, M., Akiyama, T., and Yoshida, M. (1999). Tax oncoprotein of HTLV1 binds to the human homologue of Drosophila discs large tumor suppressor protein, hDLG, and perturbs its function in cell growth control. Oncogene 18, 5967-5972. doi: 10.1038/sj.onc. 1203008

Tarhini, M., Kchour, G., Zanjani, D. S., Rafatpanah, H., Otrock, Z. K., Bazarbachi, A., et al. (2009). Declining tendency of human T-cell leukaemia virus type I carrier rates among blood donors in Mashhad, 
Iran. Pathology 41, 498-499. doi: 10.1080/00313020903041010

Tie, F., Adya, N., Greene, W. C., and Giam, C. Z. (1996). Interaction of the human T-lymphotropic virus type 1 Tax dimer with CREB and the viral 21-base-pair repeat. J. Virol. 70, 8368-8374.

Toro, C., Rodes, B., Bassani, S., Jimenez, V., Tuset, C., Brugal, M. T., et al. (2005). Molecular epidemiology of HTLV-2 infection among intravenous drug users in Spain. J. Clin. Virol. 33, 65-70. doi: 10.1016/j.jcv.2004.10.004

Trihn, D., Jeang, K. T., and Semmes, O. J. (1997). HTLV-I Tax and cytokeratin: Tax-expressing cells show morphological changes in keratin-containing cytoskeletal networks. J. Biomed. Sci. 4, 47-53. doi: 10.1007/BF02255593

Tsubata, C., Higuchi, M., Takahashi, M., Oie, M., Tanaka, Y., Gejyo, F., et al. (2005). PDZ domain-binding motif of human $\mathrm{T}$-cell leukemia virus type 1 Tax oncoprotein is essential for the interleukin 2 independent growth induction of a T-cell line. Retrovirology 2, 46. doi: 10.1186/1742-46902-46

Tsuji, T., Sheehy, N., Gautier, V. W., Hayakawa, H., Sawa, H., and Hall, W. W. (2007). The nuclear import of the human Tlymphotropic virus type I (HTLV-1) tax protein is carrier- and energy-independent. J. Biol. Chem. 282, 13875-13883. doi: 10.1074/jbc.M611629200

Turci, M., Lodewick, J., Di Gennaro, G., Rinaldi, A. S., Marin, O., Diani, E., et al. (2012). Ubiquitination and sumoylation of the HTLV-2 Tax-2B protein regulate its NF-kappaB activity: a comparative study with the HTLV-1 Tax-1 protein. Retrovirology 9, 102. doi: 10.1186/1742-4690-9-102

Turci, M., Lodewick, J., Righi, P., Polania, A., Romanelli, M. G., Bex, F., etal. (2009). HTLV2B Tax oncoprotein is modified by ubiquitination and sumoylation and displays intracellular localization similar to its homologue HTLV-1 Tax. Virology 386, 6-11. doi: 10.1016/j.virol.2009.01.003

Turci, M., Romanelli, M. G., Lorenzi, P., Righi, P., and Bertazzoni, U. (2006). Localization of human Tcell lymphotropic virus type II Tax protein is dependent upon a nuclear localization determinant in the $\mathrm{N}$ terminal region. Gene 365, 119-124. doi: 10.1016/j.gene.2005.09.043
Vousden, K. H., and Lu, X. (2002). Live or let die: the cell's response to p53. Nat. Rev. Cancer 2, 594-604. doi: $10.1038 / \mathrm{nrc} 864$

Wagner, S., and Green, M. R. (1993). HTLV-I Tax protein stimulation of DNA binding of bZIP proteins by enhancing dimerization. Science 262, 395-399. doi: 10.1126/science. 8211160

Waterston, T., and Davies, J. (1993). Could hospitals do more to encourage breast feeding? BMJ 307, 1437-1438. doi: 10.1136/bmj.307. 6917.1437

Wheeler, J. F., Beck, T. L., Klatte, S. J., Cole, L. A., and Dorsey, J. G. (1993). Phase transitions of reversedphase stationary phases. Cause and effects in the mechanism of retention. J. Chromatogr. 656, 317333. doi: 10.1016/0021-9673(93) 80807-K

Wu, K., Bottazzi, M. E., De La Fuente, C., Deng, L., Gitlin, S. D., Maddukuri, A., et al. (2004). Protein profile of tax-associated complexes. J. Biol. Chem. 279, 495-508. doi: 10.1074/jbc.M310069200

Wu, X., and Sun, S. C. (2007). Retroviral oncoprotein Tax deregulates NF-kappaB by activating Tak1 and mediating the physical association of Tak1-IKK. EMBO Rep. 8, 510-515. doi: 10.1038/sj.embor.7400931

Xiao, G., Cvijic, M. E., Fong, A., Harhaj, E. W., Uhlik, M. T., Waterfield, M., et al. (2001). Retroviral oncoprotein Tax induces processing of NF-kappaB2/p100 in T cells: evidence for the involvement of IKKalpha. EMBO J. 20, 6805-6815. doi: 10.1093/emboj/20.23.6805

Xu-Monette, Z. Y., Medeiros, L. J., Li, Y., Orlowski, R. Z., Andreeff, M., Bueso-Ramos, C. E., et al. (2012). Dysfunction of the TP53 tumor suppressor gene in lymphoid malignancies. Blood 119, 36683683. doi: 10.1182/blood-2011-11366062

Yamada, T., Yamaoka, S., Goto, T., Nakai, M., Tsujimoto, Y., and Hatanaka, M. (1994). The human Tcell leukemia virus type I Tax protein induces apoptosis which is blocked by the $\mathrm{Bcl}-2$ protein. J. Virol. 68 , 3374-3379.

Yamamoto, K., Ishida, T., Nakano, K., Yamagishi, M., Yamochi, T., Tanaka, Y., etal. (2011). SMYD3 interacts with HTLV-1 Tax and regulates subcellular localization of Tax. Cancer Sci. 102, 260-266. doi: $\quad$ 10.1111/j.1349-7006.2010. 01752.x

Yamazaki, J., Mizukami, T., Takizawa, K., Kuramitsu, M., Momose, H., Masumi, A., et al. (2009). Identification of cancer stem cells in a Taxtransgenic (Tax-Tg) mouse model of adult T-cell leukemia/lymphoma. Blood 114, 2709-2720. doi: 10.1182/ blood-2008-08-174425

Yao, J., and Wigdahl, B. (2000). Human $\mathrm{T}$ cell lymphotropic virus type I genomic expression and impact on intracellular signaling pathways during neurodegenerative disease and leukemia. Front. Biosci. 5, D138-D68. doi: 10.2741/Yao

Yin, M. J., Christerson, L. B., Yamamoto, Y., Kwak, Y. T., Xu, S., Mercurio, F., et al. (1998). HTLV-I Tax protein binds to MEKK1 to stimulate IkappaB kinase activity and NF-kappaB activation. Cell 93, 875-884. doi: 10.1016/S0092-8674(00)81447-6

Yin, M. J., and Gaynor, R. B. (1996). Complex formation between CREB and Tax enhances the binding affinity of CREB for the human T-cell leukemia virus type 1 21-base-pair repeats. Mol. Cell. Biol. 16, 31563168.

Yin, M. J., Paulssen, E., Seeler, J., and Gaynor, R. B. (1995a). Chimeric proteins composed of Jun and CREB define domains required for interaction with the human T-cell leukemia virus type 1 Tax protein. J. Virol. 69 , 6209-6218.

Yin, M. J., Paulssen, E. J., Seeler, J. S., and Gaynor, R. B. (1995b). Protein domains involved in both in vivo and in vitro interactions between human T-cell leukemia virus type I tax and CREB. J. Virol. 69, 3420-3432.

Yoshida, M., Miyoshi, I., and Hinuma, Y. (1982). Isolation and characterization of retrovirus from cell lines of human adult T-cell leukemia and its implication in the disease. Proc. Natl. Acad. Sci. U.S.A. 79, 2031-2035. doi: 10.1073/pnas.79.6.2031

Yoshida, M., Satou, Y., Yasunaga, J., Fujisawa, J., and Matsuoka, M. (2008). Transcriptional control of spliced and unspliced human T-cell leukemia virus type 1 bZIP factor (HBZ) gene. J. Virol. 82, 9359-9368. doi: 10.1128/JVI.00242-08

Zane, L., Yasunaga, J., Mitagami, Y. Yedavalli, V., Tang, S. W., Chen, C. Y., et al. (2012). Wip1 and p53 contribute to HTLV-1 Tax-induced tumorigenesis. Retrovirology 9, 114. doi: 10.1186/1742-4690-9-114

Zehender, G., Varchetta, S., De Maddalena, C., Colasante, C., Riva, A., Meroni, L., etal. (2001). Resistance to Fas-mediated apoptosis of human T-cell lines expressing human T-lymphotropic virus type-2 (HTLV2) Tax protein. Virology 281, 43-50. doi: 10.1006/viro.2000.0765

Zenz, T., Benner, A., Dohner, H., and Stilgenbauer, S. (2008). Chronic lymphocytic leukemia and treatment resistance in cancer: the role of the p53 pathway. Cell Cycle 7, 3810-3814. doi: 10.4161/cc.7.24.7245

Zhang, X., Jin, B., and Huang, C. (2007). The PI3K/Akt pathway and its downstream transcriptional factors as targets for chemoprevention. Curr. Cancer Drug Targets 7, 305-316. doi: 10.2174/156800907780809741

Zhao, L. J., and Giam, C. Z. (1992). Human T-cell lymphotropic virus type I (HTLV-I) transcriptional activator, Tax, enhances CREB binding to HTLV-I 21-base-pair repeats by protein-protein interaction. Proc. Natl. Acad. Sci. U.S.A. 89, 7070-7074. doi: $10.1073 /$ pnas.89.15.7070

Conflict of Interest Statement: The authors declare that the research was conducted in the absence of any commercial or financial relationships that could be construed as a potential conflict of interest.

Received: 25 June 2013; accepted: 29 July 2013; published online: 15 August 2013. Citation: Shirinian M, Kfoury Y, Dassouki Z, El-Hajj $H$ and Bazarbachi $A$ (2013) Tax-1 and Tax-2 similarities and differences: focus on post-translational modifications and $N F-\kappa B$ activation. Front. Microbiol. 4:231. doi: 10.3389/ fmicb.2013.00231

This article was submitted to Frontiers in Virology, a specialty of Frontiers in Microbiology.

Copyright (C) 2013 Shirinian, Kfoury, Dassouki, El-Haij and Bazarbachi. This is an open-access article distributed under the terms of the Creative Commons Attribution License (CC BY). The use, distribution or reproduction in other forums is permitted, provided the original author(s) or licensor are credited and that the original publication in this journal is cited, in accordance with accepted academic practice. No use, distribution or reproduction is permitted which does not comply with these terms. 